International Center for Public Policy

Working Paper 15-05

November 2015

Housing Bubbles and Zoning Corruption:

Evidence from Greece and Spain

\author{
Antonis M. Koumpias \\ Jorge Martinez-Vázquez \\ Eduardo Sanz-Arcega
}



International Center for Public Policy

Working Paper 15-05

\section{Housing Bubbles and Zoning Corruption: Evidence from Greece and Spain}

Antonis M. Koumpias

Jorge Martinez-Vazquez

Eduardo Sanz-Arcega

November 2015 


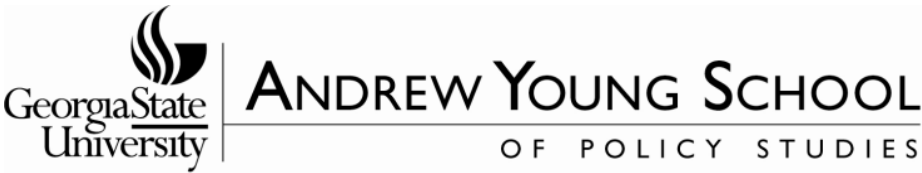

\section{International Center for Public Policy Andrew Young School of Policy Studies}

The Andrew Young School of Policy Studies was established at Georgia State University with the objective of promoting excellence in the design, implementation, and evaluation of public policy. In addition to two academic departments (economics and public administration), the Andrew Young School houses seven leading research centers and policy programs, including the International Center for Public Policy.

The mission of the International Center for Public Policy is to provide academic and professional training, applied research, and technical assistance in support of sound public policy and sustainable economic growth in developing and transitional economies.

The International Center for Public Policy at the Andrew Young School of Policy Studies is recognized worldwide for its efforts in support of economic and public policy reforms through technical assistance and training around the world. This reputation has been built serving a diverse client base, including the World Bank, the U.S. Agency for International Development (USAID), the United Nations Development Programme (UNDP), finance ministries, government organizations, legislative bodies and private sector institutions.

The success of the International Center for Public Policy reflects the breadth and depth of the inhouse technical expertise that the International Center for Public Policy can draw upon. The Andrew Young School's faculty are leading experts in economics and public policy and have authored books, published in major academic and technical journals, and have extensive experience in designing and implementing technical assistance and training programs. Andrew Young School faculty have been active in policy reform in over 40 countries around the world. Our technical assistance strategy is not to merely provide technical prescriptions for policy reform, but to engage in a collaborative effort with the host government and donor agency to identify and analyze the issues at hand, arrive at policy solutions and implement reforms.

The International Center for Public Policy specializes in four broad policy areas:

- Fiscal policy, including tax reforms, public expenditure reviews, tax administration reform

- Fiscal decentralization, including fiscal decentralization reforms, design of intergovernmental transfer systems, urban government finance

- Budgeting and fiscal management, including local government budgeting, performancebased budgeting, capital budgeting, multi-year budgeting

- Economic analysis and revenue forecasting, including micro-simulation, time series forecasting,

For more information about our technical assistance activities and training programs, please visit our website at http://aysps.gsu.edu/isp/index.html or contact us by email at gbotello1@gsu.edu 


\title{
Housing Bubbles and Zoning Corruption: Evidence from Greece and Spain
}

\author{
Antonis M. Koumpias*, Jorge Martinez-Vazquez** and Eduardo Sanz-Arcega***
}

$11 / 8 / 2015$

\begin{abstract}
The adoption of the euro in 2002 led to an unprecedented supply of cheap mortgage credit in Greece and Spain. The housing bubbles that ensued amplified developers' incentives to offer bribes for illegal construction projects. We exploit the mortgage credit windfall as the shock that induced variation in housing prices to examine the effects of the latter on zoning corruption. The empirical analysis relies on objective measures of zoning corruption at the regional level from 2003 through 2008 for Greece and from 2006 through 2008 for Spain. We employ legal indictments of zoning officials from prosecution records for Greece, which are novel to the literature, and media reports of zoning corruption scandals for Spain. Adjusting for unemployment, population, population density and college attainment, our baseline negative binomial regression estimates indicate a positive and significant relationship between housing prices and zoning corruption. Our findings are robust to a series of checks that include zero-inflated variants of the negative binomial model, and linear models that address model misspecification, omitted variables and dynamic panel bias. In the case of Spain, we are also able to analyze the sensitivity of our findings using a provincial panel that provides substantially more cross-sectional variation.
\end{abstract}

Keywords: Housing Bubbles, Corruption, Zoning, Land Use, Greece, Spain, Euro

JEL Classification: H83, K42

* Koumpias: International Center for Public Policy, Department of Economics, Andrew Young School of Policy Studies, Georgia State University, 14 Marietta Street, Atlanta, GA 30303; akoumpias1 @ student.gsu.edu.

** Martinez-Vazquez: International Center for Public Policy, Andrew Young School of Policy Studies, Georgia State University, 14 Marietta Street, Atlanta, GA 30303; jorgemartinez@gsu.edu.

*** Sanz-Arcega: Research Group in Public Economics, University of Zaragoza, 2 GranVía, 50005, Zaragoza, Spain; eduardosanzarcega@gmail.com

Acknowledgments: The authors would like to thank Victor O. Martin Martin and Luis M. Jerez Darias (GISAS Research Group, University of La Laguna, Spain) for sharing with us their data. Special thanks to Charles M. Becker and Thomas A. Mroz for very useful feedback in the early stages of this project and for detailed comments. We also thank Daron Acemoglu, Jeffrey Milyo, Jennifer Dirmeyer, Kyle Mangum, Pierre Nguimkeu, Florian Rundhammer and seminar participants at the 2015 Public Choice Society Meetings and Georgia State University's Housing Environmental Regional and Urban (HERU) Spring 2015 Brown Bag Series. 


\section{Introduction}

The creation of the European Monetary Union (EMU) in January 1, 1999 and the circulation of the euro in January 1, 2002 led to significant changes in the financing systems of many EMU member countries. Cheap credit and a surge in intra-EMU capital flows with the perception of a dramatic decrease in Southern-Europe financial risk transformed the economies of some of the peripheral countries such as Greece and Spain. The aim of this paper is to examine whether the housing bubbles experienced by Greece and Spain in the years preceding the Great Recession of 2008 exacerbated corruption of zoning officials. The mechanism under study worked as follows. Financial markets' perception of risk convergence among EMU member states significantly reduced the cost of mortgage lending in its periphery. The availability of cheap credit in Greece and Spain sparked an increase in economic activity excessively focused on housing construction. Gopinath et al. (2015) develop a theoretical framework that shows how the decline in the real interest rate in the southern EMU member states, often attributed to the euro convergence process, led to a decline in sectoral total factor productivity because capital inflows were misallocated toward investments that were not necessarily the most productive. The housing bubbles that ensued created significant new profit opportunities for housing developers while zoning officials' corruption penalties remained unchanged. As a result, the real estate boom in Greece and Spain altered housing developers' incentives to offer illegal bribes for land rezoning and officials' incentives to accept them. Other than discussions in the popular media of the potential link between the housing bubbles and zoning corruption, to date there has not been any formal testing of this relationship. ${ }^{1}$

To better understand the underlying process it is important to highlight the institutional designs that mortgage markets in Greece and Spain followed. Unlike the US experience, neither government acted as a significant mortgage insurer (like the Federal Housing Administration in the US) nor did they sponsor institutions that did so (like Fannie Mae or Freddie Mac also in the US) over the period of analysis. In fact, the Greek government guaranteed only 4 percent of standing mortgages and the Spanish government none at all. In addition, borrowers in Greece and Spain were fully exposed to the risks associated with servicing mortgage loans with draconian personal bankruptcy laws. Finally, Greek and Spanish households were able to continue to deduct primary-dwelling mortgage interest rate payments from individual income tax liability, as had been the case before the introduction of the euro. Thus, the variation in the mortgage interest rates that followed the

\footnotetext{
${ }^{1}$ For an example of a discussion of the potential link between housing bubbles and corruption in the media for the case of China see the "China Daily" of April 22 $2^{\text {nd }} 2014$ : http://www.chinadaily.com.cn/opinion/2010-10/08/content_11382933.htm. Bujko et al. (2015) uses corruption as an independent variable to explain "land grabbing" when here housing prices is the key independent variable that determines zoning corruption.
} 
introduction of the euro was the main -if not the only- mechanism affecting the decision of taking out a mortgage loan by Greek and Spanish households.

The story line we weave together in this paper starts with a dramatic drop in mortgage interest rates in Greece and Spain following EMU accession and their stabilization at historically low rates, thereafter. Figure 1 below shows the evolution of the benchmark mortgage interest rates on new housing loans in Greece and Spain from January 2000 through December 2005. This period corresponds to two years before and four after the adoption of the euro in 2002. We consider only the last two years leading to the EMU because the Spanish and, especially, the Greek economies were among the last to converge to EMU's inflationary criterion of 3 percent. For Greece, we present the trajectory of the interest rate on euro-denominated housing loans at a floating rate. It is a good benchmark of lending costs in Greece because the majority of euro-denominated housing loans from domestic credit institutions to households until December 2006 were arranged on a variable rate basis. ${ }^{2}$ In Spain, mortgages typically featured a variable (or adjustable) rate determined by the lender. We depict the evolution of the most widely used benchmark in retail-banking in Spain; i.e., the one-year EURIBOR rate (Bank of Spain, 2013).

Figure 1: Mortgage Lending Benchmark Interest Rates, January 2000 - December 2005:

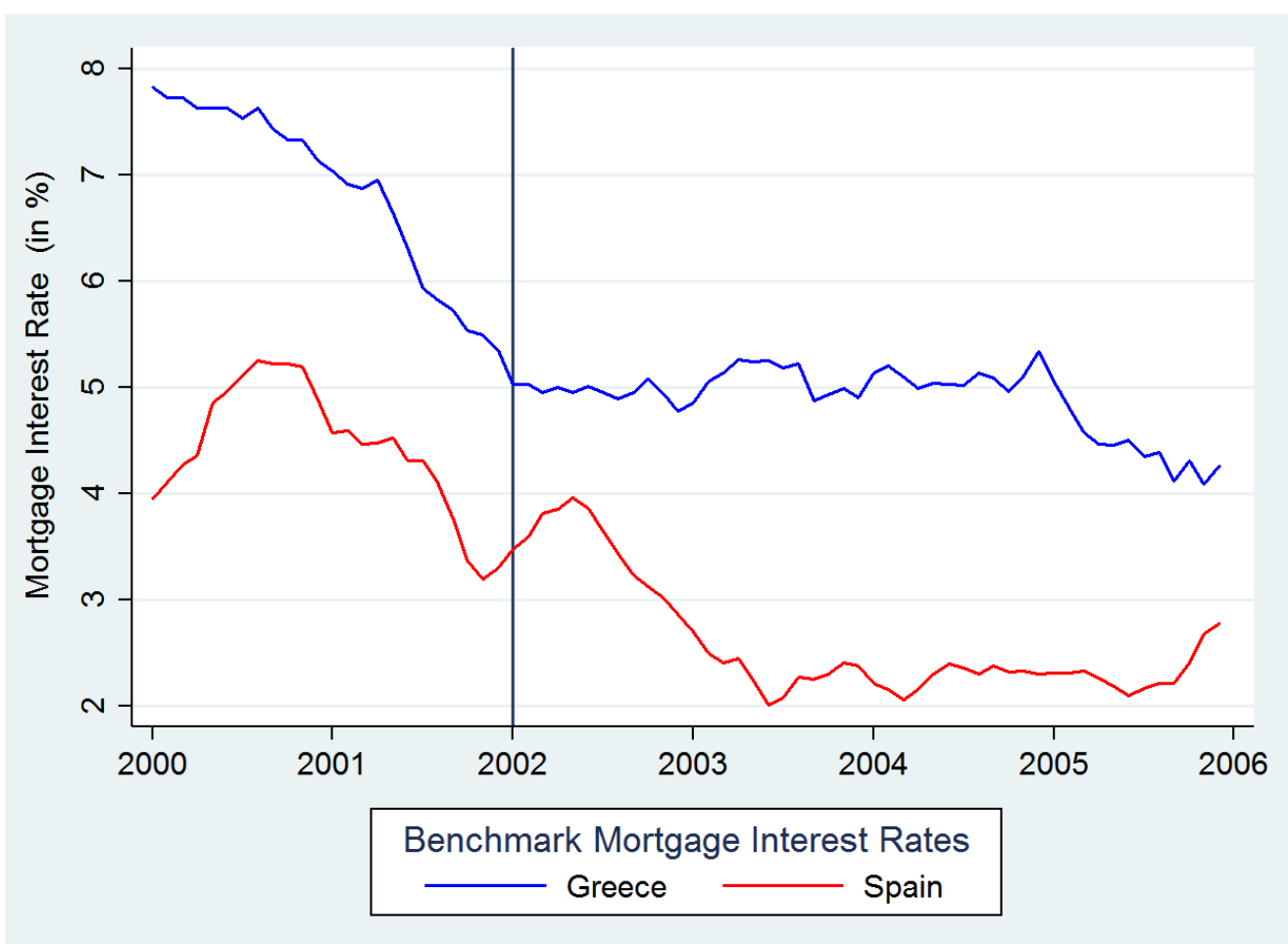

Source: Bank of Greece, Bank of Spain

\footnotetext{
${ }^{2}$ Housing loans in non-euro currencies represented 2.5 percent of the total and their rates are not presented.
} 
The average monthly rate in Greece and Spain from January 2000 through December 2001 were 6.87 percent and 4.43 percent, respectively. However, over the next two years these figures markedly declined to a 5.01 percent (a 27 percent decrease) and a 2.91 percent (a 34 percent decrease) average, respectively. These are large swings, especially considering that they represent two-year averages. Indeed, the Wilcoxon rank-sum test suggests that mortgage lending in Greece and Spain was significantly cheaper two years after accession in the EMU than before with very high precision.

These substantial reductions in the cost of borrowing prompted many more households in Greece and Spain to enter the mortgage market. Between 1999 and 2007, the average annual growth rate of loans for house purchase in Greece was 30.3 percent (the highest among Eurozone-founding member states), and in Spain 19.8 percent (third highest) whereas the volume of mortgages in the EMU as a whole grew only by 10.4 percent (ECB Structural Issues Report, 2009).

The significant growth in housing finance and the associated strong increase in housing demand resulted in a rapid increase in construction. Housing starts per 100 dwellings in Greece grew from 1.6 in 1999 to 2.1 in 2004 and in Spain from 1.5 in 1999 to 1.6 in 2007. In contrast, average housing starts in the EMU remained stable at 1.1 dwellings during the same period (ECB Structural Issues Report, 2009).

There are many potential determinants of housing prices and causality between interest rates and housing prices cannot be established from observational inference. Low interest rates do not necessarily lead to housing price increases as the recent housing markets in the US, Greece, and Spain have shown but a link between monetary policy and housing prices has been firmly documented (Sutton, 2002; Tsatsaronis and Zhu, 2004; Holt, 2009). Several studies have identified a positive relationship between housing prices and the availability of credit (mortgage lending) in Greece (Himoniti-Terroviti, 2005; Brissimis and Vlassopoulos, 2009) and Spain (Gimeno y Martínez-Carrascal, 2006; Gentier, 2012). The unprecedented supply of cheap credit due to the adoption of the euro added impetus to the pre-existing inflationary trend of nominal housing prices in Greece and Spain that followed the general inflation. This paper uses the transition to the euro and the associated windfall in mortgage lending in Greece and Spain to exploit the ensuing housing bubble as an exogenous shock that increased zoning corruption. ${ }^{3}$ This interpretation of the role played by the euro on housing prices in both countries is supported by the data. Figures 2 and 3

\footnotetext{
${ }^{3}$ We cannot exclude the possibility that zoning corruption itself may have had an effect on housing prices (reverse causality). But note that zoning corruption works to increase the supply of housing - shifting the supply curve rightward as more buildable land becomes available - and therefore putting downward pressure on housing prices. As Glaeser, Gyourko, and Saiz (2008) note, fewer and shorter bubbles with smaller price swings should be expected in regions with more elastic housing supply. Sowell (2009) finds that the largest housing price increases occurred in housing markets where local governments imposed land use restrictions which reduced the supply of available land for housing. Even if a causal loop between housing prices and zoning corruption is at play, the direction of the bias suppresses the magnitudes of our estimates and, thus, making our results more conservative.
} 
below plot the average national housing price per square meter in Greece and Spain from the adoption of the euro (January 2002) till the end of the period of our analysis (December 2008), respectively. We use the innovational outlier (IO) unit root test statistic by Clemente, Montanes, and Reyes (1998) to identify the existence of a structural break in the housing price time series.

Figure 2: Housing Prices in Greece and EMU creation (2002), $3^{\text {rd }}$ Quarter of $2002-3^{\text {rd }}$ Quarter of 2008
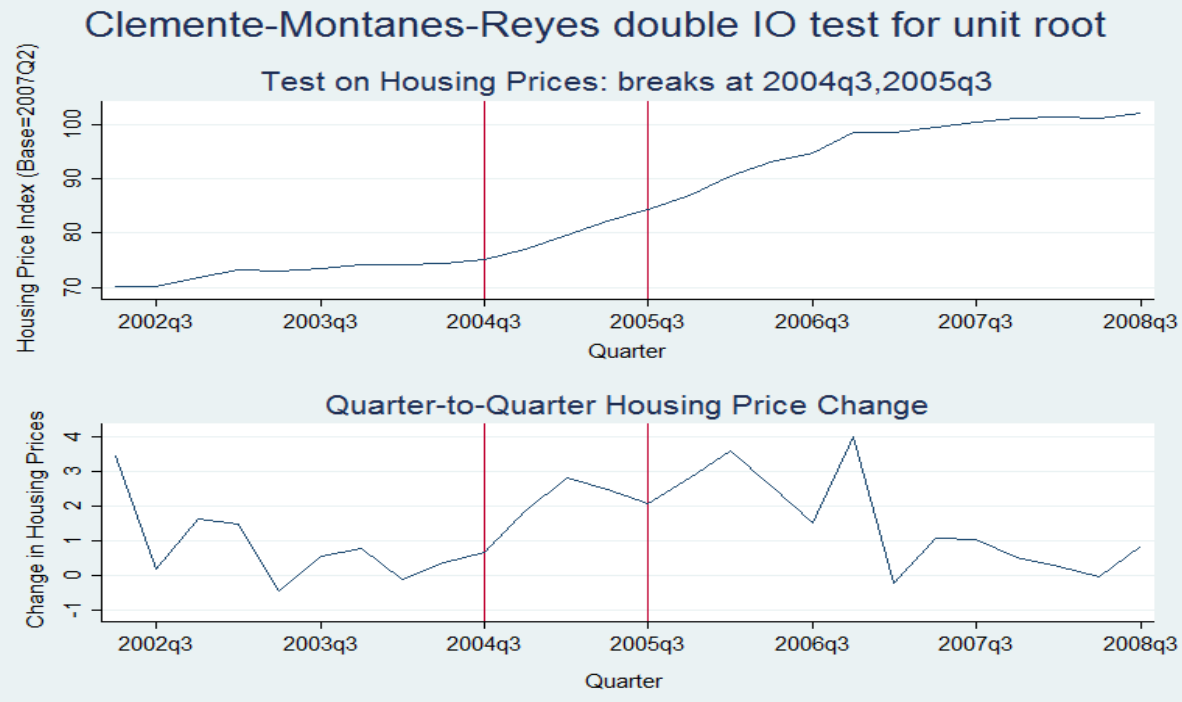

Source: Bank of Greece, Real Estate Market Analysis

Figure 3: Housing Prices in Spain and EMU creation (2002), $3^{\text {rd }}$ Quarter of $2002-3^{\text {rd }}$ Quarter of 2008

Clemente-Montanes-Reyes double IO test for unit root
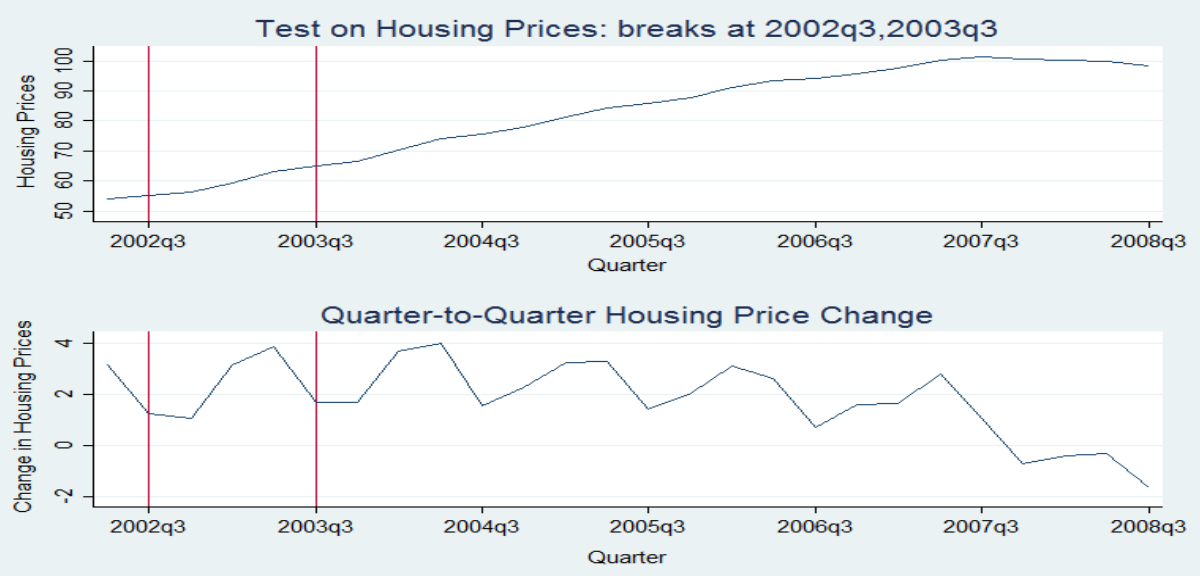

Source: Spanish Ministry of Public Works 
In both countries, a structural break in the time series of housing prices occurred within two years after the the adoption of the euro. ${ }^{4}$ This provides formal evidence that housing markets in Greece and Spain underwent substantial changes following the adoption of the euro.

Following Rose-Ackerman (1975), in this paper we define zoning corruption as "special treatments" of housing developers by zoning officials for personal gain. These "special treatments" usually took the form of granting illegal building permits in Greece and the rezoning of land tracts for residential and commercial use in Spain. The causal mechanisms that determine the supply and demand for "special treatment" may work either through the incentives individuals face or through the opportunities to actually engage in zoning corruption.

First, we discuss how increased financial incentives favored more zoning corruption. Surging housing prices in combination with fixed, inflation-adjusted construction costs (Brissimis et al., 2007) and decreasing lending costs meant greater profit opportunities for housing developers. As new housing construction projects became more profitable, this provided housing developers with larger incentives to bribe. As Rose-Ackerman (1988, p.278) puts it, "if bribes are offered there must be some prospective excess profits out of which to pay them". The size of the bribe may be related to the structure of uncertainty about the expected costs a corrupt zoning official faces (Bliss and Di Tella, 1997). In essence, the surge in housing prices increased the expected benefits to developers of extending a bribe to a zoning official (Becker, 1968).

It is important to also highlight the opportunities for zoning officials to engage in corruption. The institutional framework in Greece and Spain hugely empowered zoning officials on urban planning matters. Decision making on zoning issues was at the local level and the process was overseen by municipal authorities only. As Tanzi (1998, p.14) has noted: "decisions as to the particular use of private land (zoning laws) that determine whether the same piece of land can be used only for agriculture, and thus have low market value, or for high rise buildings, and thus can be very expensive... are prone to bribery". The natural variation in the supply of housing and zoning laws made land a commodity of differential value across regions. The opportunity for zoning corruption remained available since the zoning officials' audit probability remained unchanged. The delay of necessary institutional reforms could be attributed to the bonanza years of expanding incomes and rising tax revenues in the EU periphery (Fernández-Villaverde et al., 2013). Therefore, the expected costs to violators remained stable leaving the

\footnotetext{
${ }^{4}$ This statistic is preferred to the Perron-Vongels and and Zivot-Andrews statistics because it can capture more than one structural breaks in the time series while retaining its ability to identify only one (Baum, 2001).
} 
willingness to accept a bribe and the supply of special treatment unchanged. ${ }^{5}$ Bribing opportunities persisted as long as government-generated shortages in the form of zoning laws and regulations were in place (Lee, 1994). In a way, the institutional setup allowed zoning officials to function as "discriminating monopolists fixing market clearing rates for the services being offered" (Jagannathan, 1986).

For our baseline results, and based on the availability and nature of the data, we estimate separate negative binomial models for each country. We model corruption counts using monthly regional data from 2003 through 2008 in Greece and quarterly regional data from 2006 through 2008 in Spain. We find a positive and significant association between housing prices and zoning corruption. The non-constant marginal effects indicate that zoning corruption increased at a faster rate than housing prices. Our baseline findings are robust to a series of robustness checks. We estimate zero-inflated variants of the unconditional negative binomial model to test whether our baseline model is mis-specified. We investigate different specifications to address any omitted variable bias concerns. We estimate linear models to assess the validity of the "memoryless" property embedded in the count data analysis, and the importance of dynamic panel bias, particularly for the case of Spain.

The rest of the paper is organized as follows. Section 2 presents a review of the empirical literature on the determinants of corruption. Section 3 discusses the data and methodology and Section 4 presents the baseline results. Section 5 discusses econometric issues pertaining to our analysis, and addresses them in a succession of robustness checks. Section 6 concludes.

\section{Review of the Literature on the Determinants of Corruption}

Much of the empirical literature on corruption has been hampered by the use of subjective measures of corruption and the lack of a proper identification strategy. The first wave of empirical studies of the determinants of corruption, often cross-national analyses, made use of subjective measures of corruption from survey data from Transparency International Global Corruption Barometer, the United Nations World Value Survey, and the World Bank Worldwide Governance Indicators (WGI). ${ }^{6}$ The main

\footnotetext{
${ }^{5}$ Of course, housing bubbles make acceptance of a bribe relatively more appealing to zoning officials when it is not accompanied by a tightening of the penalties associated with misconduct (Aidt, 2003).

${ }^{6}$ There has been a host of studies based on the survey's data. Just to mention some of the findings in this literature on the determinants of corruption, Serra (2006) conducts a cross-country Global Sensitivity meta-analysis and finds that income, history of democratic institutions, Protestant religion, colonial heritage, and political instability are all robust determinants of corruption. Mauro (1997), Beets (2005), Lederman et al. (2005), and Cheung and Chan (2008) report a negative association between education level and corruption; however, Frechette (2006) arrives at the opposite conclusion. Beets (2005) finds that higher levels of unemployment are associated with higher corruption and Emerson (2006) finds a negative relation between market competition and subjective measures of corruption. Lambsdorff (2006), Svensson (2005), Beets (2005), Treisman (2000), Husted (1999), Mauro (1997), and Chang (2010) find a negative association between income level and corruption. On the contrary, Braun and Di Tella (2004) and Frechette (2006) find GDP per capita to be positively correlated with corruption using panel data.
} 
weakness of this literature is some well-known shortcomings with the use of subjective measures of corruption. Subjective measures of corruption rely on perceptions or on personal experiences of bribery. Surveys use responses of businesses or households to questionnaires that inquire whether or not they have ever given an illegal payment to a public official, or their opinion about how corrupt the government is. However, individuals or businesses may want to mask their actual behavior in survey responses to avoid potential penalties or further actions. As a result, subjective measures of corruption may be plagued by imprecision (Kaufman et al., 2010). In addition, systematic biases may undermine empirical analysis when different classes of respondents differ by design, or when the ideological orientation of the institution matters. In addition, subjective assessments might be driven by "halo effects"; i.e., negative evaluations when conditions are worsening and vice versa. Finally, when different data providers use each other's evaluations, endogeneity is introduced since perception errors are correlated. In this paper we bypass the aforementioned challenges by employing objective counts of corruption. We measure actual counts of zoning corruption coming from public records in Greece counts and media reports in Spain. The data are described extensively in section 3.1 below.

The literature on corruption has also struggled with the lack of proper identification strategies. Due to the practical difficulties in conducting natural field experiments on corruption, only very limited evidence from the field exists. And by design, these studies can only reveal effective approaches to curbing corruption rather than identifying its causal determinants. Olken (2007) did carry out a field experiment in over 600 Indonesian village road projects to find that government audits reduced corruption significantly whereas increased grassroots participation in monitoring had negligible effects. The absence of clear-cut comparative case study settings has prevented the use of standard quasi-experimental techniques to study corruption. As a result, the methodology employed has been typically restricted to either instrumental variable (IV) and dynamic panel techniques or has exploited instances of exogenous, natural variation in the determinants of corruption.

Some of these studies include Ferraz and Finan (2009) who use audits of incumbent municipal politicians to construct enhanced measures of corruption that control for unobserved characteristics of the locale. Based on reduced-form as well as IV techniques, Brollo et al. (2013) report that an increase in federal transfers in Brazil by 10 percent amplifies the incidence of severe corruption by about 16 percent. Following the same designs, Dong and Torgler (2013) report that Chinese provinces with resource abundance exhibit greater corruption whereas higher educational attainment and fiscal decentralization leads to significantly less corruption. Batzilis (2014) uses a IV approach to show that electoral competition at the municipality level reduced public spending corruption in Greece. Also, he finds a higher incidence of corrupt spending in less populated, more rural municipalities. Del Monte and Papagni 
(2007) apply an autoregressive distributed lag model to regional data from 1963 through 2001 in Italy to investigate the determinants of corruption, defined as crimes against the public administration reported to the police. They find that per capita GDP, public expenditure on consumption goods and services, and institutional and judiciary changes are the most important contributors to public corruption in Italy.

A different strand of the empirical literature has relied on instances of natural resource windfalls as sources of exogenous variation to examine corruption. Maldonado (2010) exploits exogenous variation in economic conditions in Peru from mineral price shocks due to the relative abundance of mineral resources across regions. His results suggest that the increases in transfer funds due to positive shocks in international mineral prices affected corrupt practices in citizens' interactions with public officials, and that these corrupt practices differed according to the size of the shock. Caselli and Michaels (2013) use variation in oil output among Brazilian municipalities that was exogenously dictated by world oil prices to find evidence of embezzlement in oil-rich municipalities. It is in this latter strain of the empirical literature where our paper fits. Similarly to those papers, we exploit variation in corruption incentives (rents reflected by housing prices) that naturally occurred following the adoption of the euro in Greece and Spain. We focus on a period of housing bubbles as documented by structural breaks in the residential property price time series. The steep acceleration in housing prices allows us to identify their role in zoning officials' corruption motives separately from other confounding factors of corruption.

\section{Empirical Analysis}

We conduct separate empirical analyses for Greece and Spain. We refrain from pooling the observations from the two countries because that would be responsible for a large fraction of the overall variation. Even though Greece and Spain are not dramatically different in many respects, there are significant institutional and economic differences. ${ }^{7}$ Furthermore, the observations of zoning corruption are coming from distinct data generating processes for each country. This is why we estimate parameters using a panel of a single country at a time, and, thus, exploit greater cross-sectional variation due to the regional disaggregation.

Given the within-country nature of our study, we assume institutional homogeneity; i.e., relative wages of zoning officials and anti-corruption efforts by auditors are equal across regions, within country. This may be quite appropriate given the nationwide salary base and trends that applied in each country. It is also an empirical necessity because controls of institutional quality such as "Rule of Law" and "Quality of the

\footnotetext{
${ }^{7}$ For example, Golden (2015) argues that "there is little likelihood that Spain, for instance, will tumble to Greece's...levels of corruption".
} 
Bureaucracy" are only available at the national level for the period of analysis. ${ }^{8}$ And even though the low mortgage interest rates that triggered the housing bubbles in Greece and Spain were uniformly available across regions, it could be argued that there may still be differences in the quality of public administration. This would imply substantial regional heterogeneity in the level of corrupt activities but does not seem to be the case as discussed below. Our analysis captures regional institutional differences through the inclusion of education attainment as a control variable. Education is often regarded as a proxy of overall development and has been found to correlate with enhanced government performance and reduced levels of evasion. ${ }^{9}$ Lastly, any time-invariant, region-specific characteristics we failed to control are captured by regional dummies. Arguably, these should capture the bulk of institutional differences among regions given the slowly-adjusting nature of institutional quality.

\subsection{Data}

Our main dependent variable is an objective (non-perception, non-survey-based) metric of corruption: legal indictments of zoning officials from prosecution records in Greece, and zoning corruption scandals reported in the media in Spain. In both cases, zoning corruption is measured at the regional level. The observations of the zoning corruption are non-negative and discrete; thus, they qualify as count data (Bujko et al., 2015).

In the case of Greece, information comes from monthly prosecution records of zoning officials by the Inspectors-Controllers Body for Public Administration of Greece from January 2003 through December 2008. This is an internal audit service of the public administration which independently monitors all public officials in Greece. ${ }^{10}$ There are six characterizations of public administration malpractices, each of which reflects a different degree of corruption intensity. We only use the most extreme case of zoning corruption intensity to make results for Greece directly comparable to those for Spain. More importantly, it allows us to rule out the possibility that increased counts of zoning corruption are due to the reporting of multiple prosecutions of the same defendant. The use of corruption audits data is a relatively recent development in the literature, but it is becoming more prevalent (Olken, 2007; Ferraz and Finan, 2009; Caselli and Michaels, 2013; Brollo et al., 2013).

\footnotetext{
${ }^{8}$ An exception is the European Quality of Government Index (EQI), which is the result of novel survey data on corruption and governance at the regional level within the EU, conducted first in 2010 and then again in 2013. However, these survey data only cover years later than the scope of our analysis

${ }^{9}$ See, for example, Mauro (1997), Beets (2005), Lederman et al. (2005), and Cheung and Chan (2008).

10 The data were obtained during our personal visit to the Inspectors unit in Athens in August 2014. Inspections are delineated into 16 categories that fully describe the nature of the violation. The six corruption-related categories incorporated in our measure of the dependent variable are: (1) Corruption - Other Legal Indictments; (2) Illegal Action; (3) Organizational Problems; (4) Violations of Code of Conduct; (5) Violation of Transparency; (6) Omission of Designated Action.
} 
The data on zoning corruption in Spain were obtained from the GISAS Research Group at the University of La Laguna in Spain. Although the original dataset comprised corruption scandals from 2000 to 2008, just 3 per cent of the counts were recorded for the period 2000-2005. This is the case because information for these two periods was collected independently by different sources. To prevent measurement error from combining information by two different data generating processes, we discard any observations prior to 2006. The dependent variable for Spain represents the quarterly number of media reports of zoning corruption scandals from the first quarter of 2006 to the fourth quarter of 2008. These scandals involve real estate crimes committed by zoning officials at the municipal level, and are aggregated up to the regional level. The calculus of corruption counts is based on web-scrapping of media reports. This approach of corruption enumeration is not new. It has been used in previous studies of public corruption in Spain (Fundación Alternativas, 2007; Costas-Pérez et al., 2012), financial scandals and election law violations in Japan (Nyblade and Reed, 2008) and oil revenue embezzlement in Brazil (Caselli and Michaels, 2013). As a matter of fact, the same dataset has already been used in publications that examine the impact of zoning corruption on political outcomes (Martín-Martín et al., 2010; Jerez-Darias et al., 2012).

Housing prices is the key explanatory variable used in the analysis and reflects profit incentives for bribing. They are measured in euros per square meter. We use this normalization to account for any effects the size of property may have on its price. Considering merely contemporaneous prices we cannot explore whether a rise in housing prices triggered zoning corruption in a future time period. To account for the time-consuming process a corruption count takes to mature we use 18-month housing price lags. ${ }^{11}$ This corresponds to the average duration for a dwelling to be constructed in Greece and accounts for the time required for the gradual exposure and media coverage of a zoning scandal indictment in Spain.

For Greece, housing prices are constructed based on the Housing Price Index compiled by the Real Estate Market Analysis Section of the Bank of Greece. Four time series are available of which only two perfectly match our regional disaggregation for Greece. We interact these time series with actual median residential property prices from Mitrakos et al. (2014) to introduce further cross-sectional housing price variation. The latter study provides information on 28 cities across 12 regions of Greece. For the one region which is not covered in Mitrakos et al. (2014), we use its neighboring region's housing price information. Our results are robust to the exclusion of the region for which we lack a local housing indicator. Housing prices are expressed as housing prices per square meter in a region of Greece.

\footnotetext{
${ }^{11}$ The use of lags of independent variables to study corruption is not novel. In a study of the regional determinants of corruption in Italy, Del Monte and Papagni (2007) also resort to lagged terms because "time is needed for bargaining" and inaccuracies may arise between committing and reporting the corrupt activity.
} 
For Spain, housing prices were extracted from the website of the Spanish Ministry of Public Works and Transport and match regions perfectly. They represent property values of new housing units per square meter from 2000 through 2008 in quarterly frequency. We use values earlier than 2006 to create the necessary housing price lags without sacrificing any zoning corruption observations when differencing.

Next, we use the number of new building permits to approximate the window of opportunity of zoning corruption. Figures 4 and 5 below plot zoning corruption and building permit averages for each region in Greece and Spain, respectively, without adjusting for regional population. However, confounding will arise if housing prices and zoning corruption have common causes that we fail to condition on.

Figure 4: Average Zoning Corruption and New Building Permits per Region in Greece

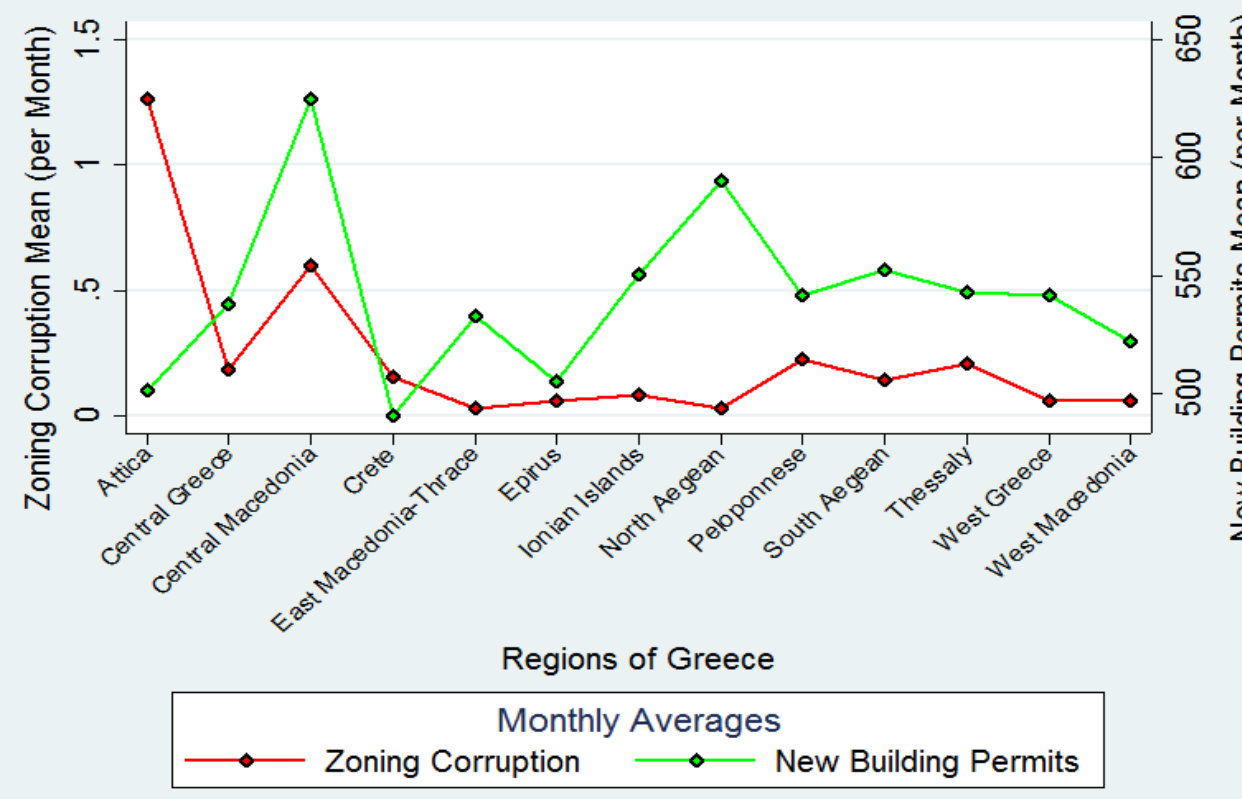


Figure 5: Average Zoning Corruption and New Building Permits per Region in Spain

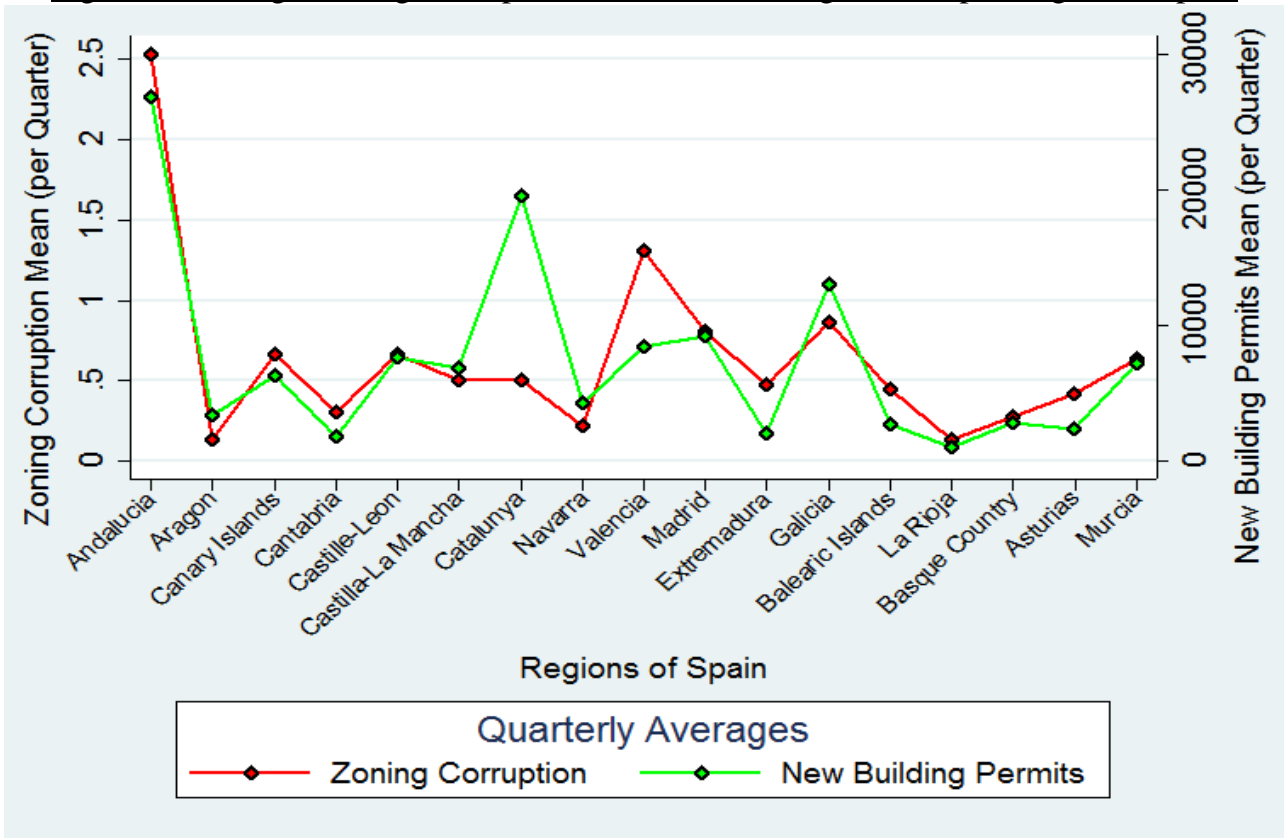

Note that the ratio of the zoning corruption mean to the building permit mean is fairly constant across regions within Greece and within Spain. First, this is encouraging for the validity of our design because it illustrates that the opportunity to engage in zoning corruption followed a common pattern, across regions, as the institutional and judicial uniformity we assumed, within country, would suggest. Second, the predictive power of building permits demonstrates its appropriateness as the exposure variable in our modeling. In Greece, the notable deviation from the corruption-permit country ratio is for Attica, the region of Athens. This could be explained by its extremely high population density (highest among all 30 EMU regions we consider). If population density is operationalized through higher-rise buildings then the number of new building permits need not be as large as in other regions. In addition, the fact that the homeownership rate in Greece was high even before the adoption of the euro implies smaller new building needs at the largest population center. As a matter of fact, many new residential properties in Greece were constructed as second-home properties in regions where tourism is prevalent such as the South and North Aegean and the Ionian Islands for residents from the large cities. The fact that Central Macedonia, a region of Thessaloniki, the second largest city in Greece, exhibits a large number of new building permits could be attributed to the presence of a major tourist destination in the region (Chalkidiki) where second-home housing construction grew substantially post-EMU. In Spain, Catalonia stands out with a much smaller zoning corruption to building permit ratio compared to other regions in Spain. 
Its capital, Barcelona, is considered a top haven for expatriate retirees with an estimated population of over $35,000 .{ }^{12}$ The associated increased demand for housing is one of the contributing factors for such outlier behavior. And, as in the Greek case, demand from individuals of landlocked regions that experienced steep growth (e.g. Madrid) seeking a coastal second-home could also explain part of the excess construction.

Besides housing prices and building permits, we allow for other factors to influence the proclivity of public officials towards corruption on the basis of findings in the within-country literature on the determinants of corruption. For our baseline estimation we adjust for the unemployment rate, population, population density, and the enrollment rate in tertiary education. All control variables are obtained from Eurostat's regional statistics portal. They are available at the regional level (EU classification: NUTS level 2); the latter three in annual frequency and unemployment in quarterly frequency.

The measurement of education attainment via enrollment rates in tertiary (higher and continuing) education may be subject to bias because large metropolitan areas feature more tertiary educational institutions, skewing enrollment rates higher in more populous regions. However, this concern is mitigated by the fact that public tertiary education is uniformly provided across regions of Greece and Spain, a feature that is quite common across public continental European education systems. Literacy rates are an alternative measure commonly found in past empirical research but would have yielded negligible variation across regions given the EMU context.

Population measures the number of inhabitants in a region (all ages, both sexes). A combined reading of Figures A.1 through A.4 in the Appendix reveal that construction activity is positively related to increases in population. The highest counts of zoning corruption are recorded in the most populous regions in both Greece and Spain; Attica and Andalucía, respectively. This mechanically widens the window of opportunity for corruption in more populous regions. Thus, we include population to control for any population size effects (level effects) on the counts of zoning corruption.

Population density measures the number of inhabitants in a region (all ages, both sexes) per square kilometer. We believe that population density is an important determinant of zoning corruption because it affects its monitoring intensity. In densely populated regions, more people compete for land. This produces more checks on the performance of the zoning officials and, subsequently, less corruption. As a matter of fact, in Greece most zoning corruption is exposed after adjacent residential property owners file a complaint to the public administration auditors. This, in turn, triggers investigation of the case by the auditors. If any misconduct on behalf of the zoning official is revealed, arraignment ensues. Our zoning corruption

\footnotetext{
129 Top Havens for Expat Retirees: http://money.usnews.com/money/blogs/on-retirement/2014/08/28/9-top-havens-for-expatretirees
} 
observations for Greece come from the subset of arraigned officials that were, eventually, legally indicted. In essence, more "eyes" provide more checks of corrupt zoning activity.

We use the unemployment rates of individuals aged 15 years or over for both sexes as a predictor of housing demand. GDP could have alternatively been used to proxy housing demand. However, since GDP is more strongly correlated with housing prices this would have attenuated our coefficient of interest. ${ }^{13}$

Tables A.1 and A.2 in the Appendix provide summary statistics for Greece and Spain, respectively. Table A. 3 contains a short description of the variables used as well as their source. Tables A.4 and A.5 report correlation coefficients between all of the study variables for Greece and Spain, respectively.

\subsection{Estimation approach}

We model zoning corruption $\left(Y_{i t}\right)$ as a function of housing prices $\left(H P_{i t}\right)$ and adjust for educational attainment, unemployment, population, population density, and number of new building permits $\boldsymbol{X}_{i t}$ issued in region $i$ at time $t$. We also use housing price lags to account for the inherently slowly process of construction. Time-invariant, region-specific variation is captured by the regional dummy variables $\alpha_{i}$.

Because the count of zoning corruption includes many zero values, our modeling strategy needs to take this into account. The coexistence of a high proportion of zeros along with large values of counts makes it difficult for a linear specification to appropriately model corruption. Assumptions such as normally distributed residuals and constant variance required for identification in an ordinary least squares regression model rarely fit count data. The Poisson and the negative binomial are the primary specifications used in the literature under these conditions (Cameron and Trivedi, 2005).

A Poisson data generating process assumes the rate parameter $\alpha_{i} \exp \left(\boldsymbol{X}_{\boldsymbol{i t}}^{\prime} \boldsymbol{\beta}\right)$ is known when, in fact, it is a random variable itself. Further, Poisson models require that the conditional mean is equal to the conditional variance. In our case, the latter exceed the former for both Greece and Spain. In the presence of overdispersion $\left(\lambda_{i}\right)$, negative binomial models are preferred to Poisson ones due to their flexibility in modeling the moments of the observed distribution of corruption. Namely, negative binomial models permit the conditional mean to differ from the conditional variance. The superiority of the negative

\footnotetext{
${ }^{13}$ Indeed, housing prices are more collinear with GDP $(\rho=0.29$ for Greece; $\rho=0.68$ for Spain $)$ than unemployment ( $\rho=-0.28$ for Greece; $\rho=-0.14$ for Spain)
} 
binomial to the Poisson models in fitting identified corruption in Greece and Spain can be seen, respectively, in Figures 6 and 7 below.

Figure 6: Poisson and Negative Binomial Fits of Zoning Corruption, Greece:

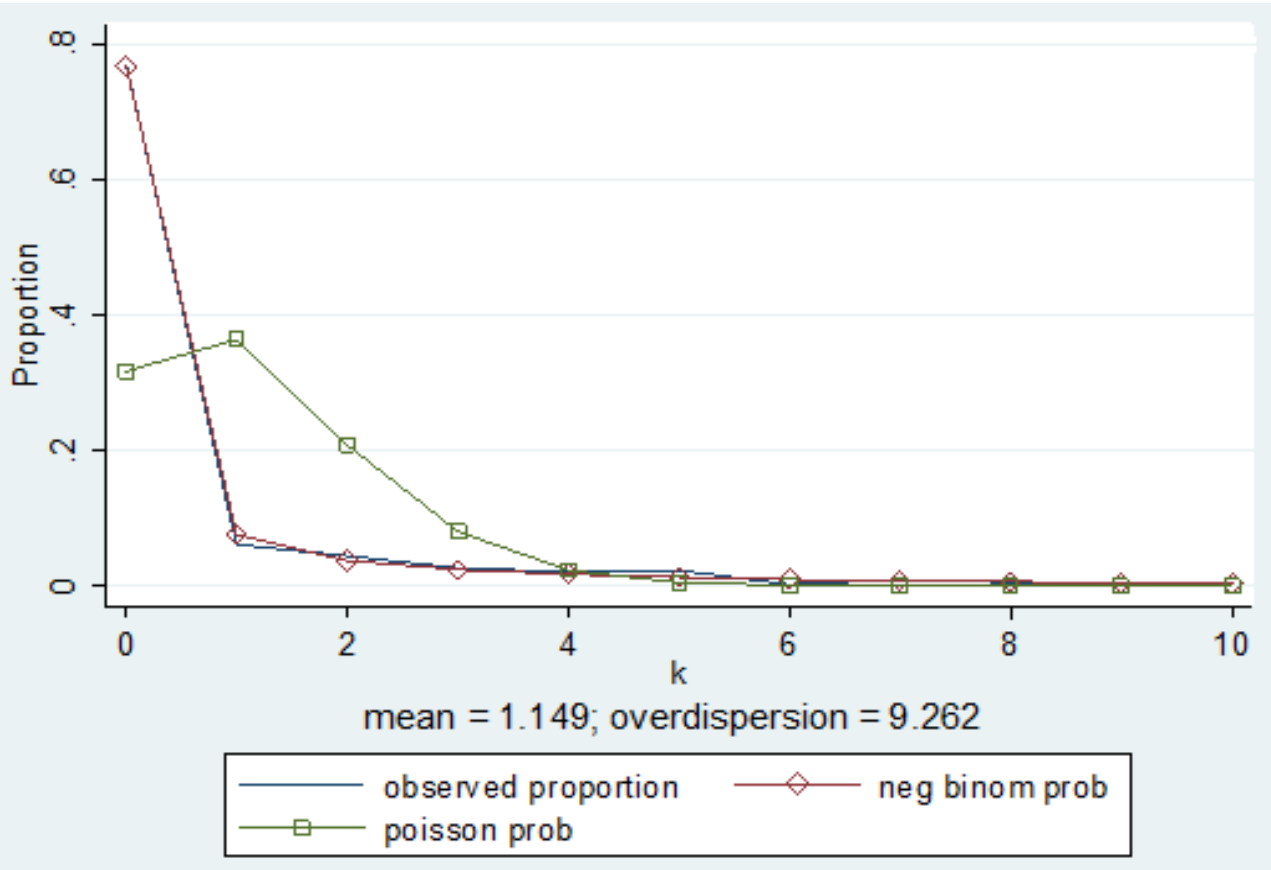

Figure 7: Poisson and Negative Binomial Fits of Zoning Corruption, Spain:

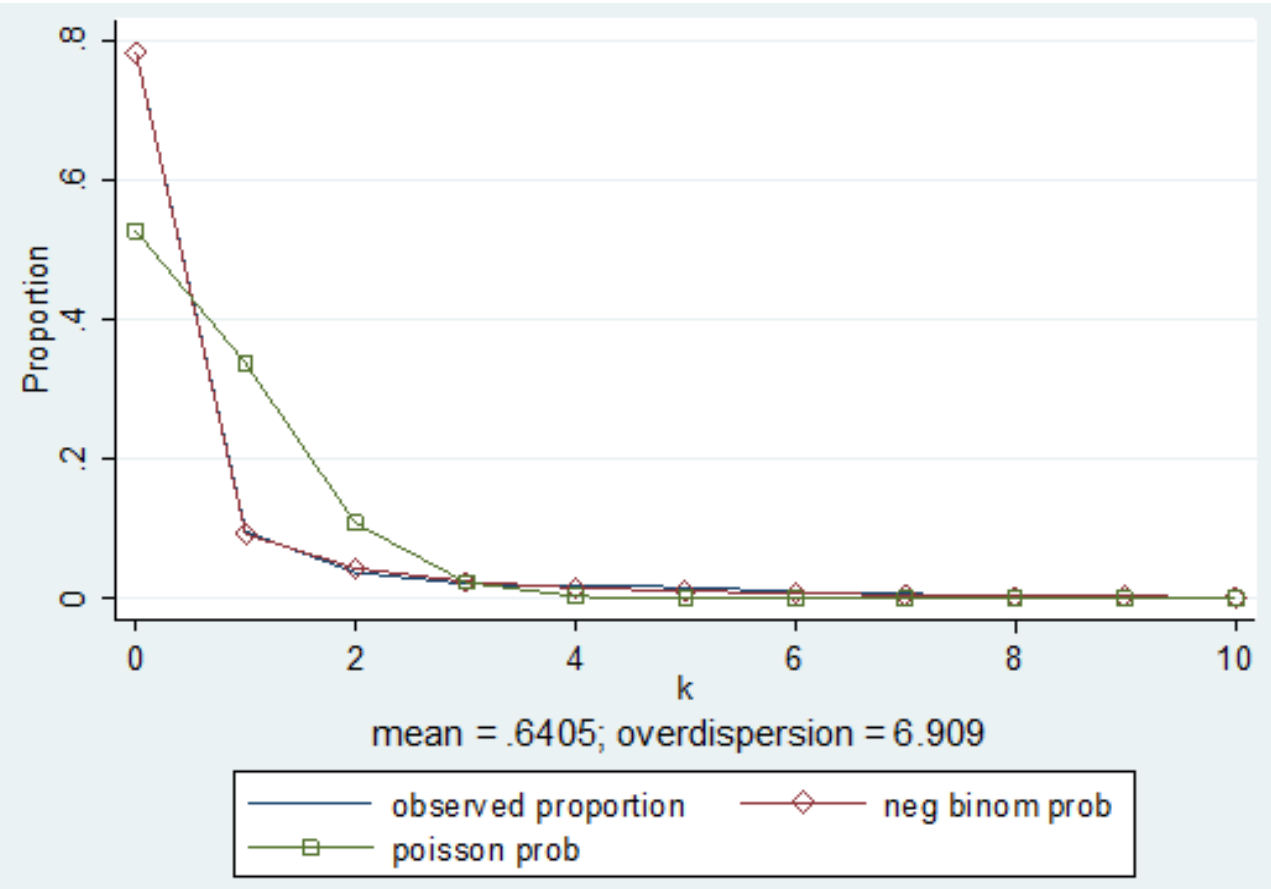


Likelihood-ratio tests formally confirm the validity of our choice of negative binomial as opposed to Poisson models, too.

Hausman, Hall and Griliches (1984) use the Andersen's conditional log likelihood to estimate fixedeffects negative binomial models. Allison and Waterman (2002) suggest that Hausman et al. (1984) did not formulate a true fixed effects model in the mean of the random (dependent) variable because they did not control for all time invariant covariates. Their model layers the fixed effect into the heterogeneity portion of the model and not the conditional mean. This portion is then conditioned out of the distribution to produce the model Hausman et al. (1984) estimate. However, the parameters that are conditioned out of the likelihood function do not correspond to different intercepts in the log-linear decomposition of the overdispersion parameter. Allison and Waterman (2002) propose an unconditional negative binomial model that uses dummy variables to represent fixed effects. We follow their approach and specify 13 and 17 regional dummy variables for Greece and Spain, respectively. The probability mass function of a single count $y_{i t}$, its mean $E\left(y_{i t}\right)$ and variance $\operatorname{Var}\left(y_{i t}\right)$ is obtained from

$$
\begin{gathered}
f\left(y_{i t} \mid \mu_{i t}, \lambda_{i}\right)=\frac{\Gamma\left(\lambda_{i}+y_{i t}\right)}{\Gamma\left(\lambda_{i}\right) \Gamma\left(1+y_{i t}\right)}\left(\frac{\mu_{i t}}{\mu_{i t}+\lambda_{i}}\right)^{y_{i t}}\left(\frac{\lambda_{i}}{\mu_{i t}+\lambda_{i}}\right)^{\lambda_{i}} \\
E\left(y_{i t}\right)=\mu_{i t} \\
\operatorname{var}\left(y_{i t}\right)=\mu_{i t}\left(1+\frac{\mu_{i t}}{\lambda_{i}}\right)
\end{gathered}
$$

where the mean $\mu_{i t}$ fluctuates with time but the overdispersion parameter $\lambda_{i}$ is time-invariant.

By design, the dependent variable could be interpreted as a rate of zoning corruption; zoning corruption cases per number of new building permits issued in a month in Greece or a quarter in Spain. ${ }^{14}$ Therefore, our estimates should be adjusted for the amount of opportunity for corruption events. To do so, we introduce an exposure variable which reflects the amount of exposure over which the outcome events were observed for each region-time observation. Construction permits are chosen because they captured the window of bribing opportunities to a zoning official. In the polar case, if zero building permits were issued, no zoning corruption could have been detected.

We, implicitly, assume that the likelihood of zoning corruption events did not change over time. That is, the denominator of the zoning corruption rate did not affect the numerator beyond opportunity. If, for

\footnotetext{
14 To transform the dependent variable from a rate back to a count one can multiply both sides of the estimated equation by the exposure variable. Logging yields a right side of the equation that includes the natural logarithm of the exposure variable. This is called the offset variable and is required to have a coefficient of 1. Moving the offset variable back to the left side of the equation turns the count back into a rate.
} 
example, it took auditors and prosecutors different times to clear a zoning corruption case then arrival time of each zoning corruption event was not just a matter of exposure. But, there is no reason to believe that this was the case. In Greece, we use corruption events of only the same intensity, thus, clearing time of each prosecution should have been the same. For Spain the assumption would be violated if reporting of each case differed by the time it took to be either judicially processed or released in the news. We discard these possibilities because of the uniformity of the judicial system in Spain and the fact that the arrival time of zoning corruption scandals to all media outlets is concurrent by briefs from the Associated Press in Spain. Indeed, media coverage of zoning corruption across regions of Spain is not a concern as 97 percent of the zoning corruption scandals locally reported also appeared in national media.

Our baseline specification is the unconditional negative binomial dummy variable model below:

$$
\ln \left(\mu_{i t}\right)=\beta_{1} H P I_{i t}+\boldsymbol{\beta}_{2} \boldsymbol{X}_{i t}+\boldsymbol{I}\left(\text { Region }_{i}\right)+\beta_{3} \ln \left(\text { Permits }_{i t}\right)
$$

where $\beta_{3}=1$. It is also referred to as the NB2 model (Cameron and Trivedi, 1998).

\section{Results}

Recall that the Poisson model is a special case of the negative binomial one - it restricts the overdispersion parameter $\lambda_{i}$ to be equal to zero. To test whether $\lambda_{i}=0$, we perform a likelihood-ratio test. Standard errors are clustered by region to allow for intra-regional correlation.

\subsection{The Case of Greece}

The likelihood-ratio test of $\lambda_{i}=0$ has an associated $\chi^{2}$ value of 132.93 which suggests the probability that these observations were generated under the assumption that $\lambda_{i}=0$ is zero. This finding favors the use of negative binomial models in expense of the Poisson ones.

Parameter estimates are therefore based on negative binomial regression models. The coefficient of interest is $\beta_{1}$ and shows the impact of the housing prices during the bubble on zoning corruption. Given the model's non-linearity, its interpretation is not straightforward. Therefore, the focus in Table 6 is only on the signs of the coefficients. Table 7 presents marginal effects that allow for a more natural interpretation of the coefficients' magnitudes. 


\begin{tabular}{|c|c|c|}
\hline Variables & $\begin{array}{c}(1) \\
\text { Contemporaneous Housing Prices }\end{array}$ & $\begin{array}{c}(2) \\
\text { 18-month Housing Price Lag }\end{array}$ \\
\hline Housing Prices $\left(€ / m^{2}\right)$ & $\begin{array}{c}0.000182 \\
(0.000399)\end{array}$ & $\begin{array}{c}0.00194^{* *} \\
(0.000879)\end{array}$ \\
\hline Unemployment & $\begin{array}{l}0.0811 \\
(0.179)\end{array}$ & $\begin{array}{c}0.140 \\
(0.243)\end{array}$ \\
\hline Population Density & $\begin{array}{c}-0.112^{* * *} \\
(0.0226)\end{array}$ & $\begin{array}{c}-0.0973^{* * *} \\
(0.0300)\end{array}$ \\
\hline Population & $\begin{array}{l}0.00002^{* * *} \\
(0.000002)\end{array}$ & $\begin{array}{c}-0.000058 \\
(0.000062)\end{array}$ \\
\hline Education & $\begin{array}{c}0.386^{* * *} \\
(0.107)\end{array}$ & $\begin{array}{c}-0.0152 \\
(0.190)\end{array}$ \\
\hline Central Greece & $\begin{array}{c}-40.51^{* *} \\
(19.17)\end{array}$ & $\begin{array}{l}-300.7 \\
(224.5)\end{array}$ \\
\hline Central Macedonia & $\begin{array}{l}-62.62^{* * *} \\
(18.83)\end{array}$ & $\begin{array}{l}-214.9 \\
(140.5)\end{array}$ \\
\hline Crete & $\begin{array}{c}-39.80^{* *} \\
(18.86)\end{array}$ & $\begin{array}{l}-294.2 \\
(220.7)\end{array}$ \\
\hline East Macedonia-Thrace & $\begin{array}{c}-43.94 * * \\
(19.13)\end{array}$ & $\begin{array}{l}-298.7 \\
(221.1)\end{array}$ \\
\hline Epirus & $\begin{array}{c}-39.64 * * \\
(19.45)\end{array}$ & $\begin{array}{l}-314.8 \\
(237.8)\end{array}$ \\
\hline Ionian Islands & $\begin{array}{l}-27.71 \\
(17.96)\end{array}$ & $\begin{array}{l}-316.9 \\
(245.8)\end{array}$ \\
\hline North Aegean & $\begin{array}{r}-34.69^{*} \\
(18.98)\end{array}$ & $\begin{array}{l}-322.4 \\
(246.4)\end{array}$ \\
\hline Peloponnese & $\begin{array}{l}-41.31^{* *} \\
(19.27)\end{array}$ & $\begin{array}{l}-298.1 \\
(222.3)\end{array}$ \\
\hline South Aegean & $\begin{array}{l}-32.59^{*} \\
(18.56)\end{array}$ & $\begin{array}{l}-312.9 \\
(239.0)\end{array}$ \\
\hline Thessaly & $\begin{array}{l}-44.67^{* *} \\
(19.26)\end{array}$ & $\begin{array}{l}-287.2 \\
(212.1)\end{array}$ \\
\hline West Greece & $\begin{array}{c}-43.20^{* *} \\
(18.86)\end{array}$ & $\begin{array}{l}-290.6 \\
(215.3)\end{array}$ \\
\hline West Macedonia & $\begin{array}{c}-38.38^{* *} \\
(19.37)\end{array}$ & $\begin{array}{l}-318.3 \\
(241.4)\end{array}$ \\
\hline Constant & $\begin{array}{c}19.14 \\
(18.98)\end{array}$ & $\begin{array}{c}324.9 \\
(258.5)\end{array}$ \\
\hline Observations & 936 & 702 \\
\hline
\end{tabular}

Columns (1) and (2) of Table 6 above present the results of specifications using contemporaneous and lagged housing prices, respectively. Column (2) suggests that for a one euro per square meter increase in monthly housing prices, the difference in the logs of expected counts of zoning corruption is expected to increase by 0.00194 unit, while holding the other controls constant. This relationship is statistically significant at the 5 percent level.

Unemployment is positively but not significantly correlated with zoning corruption. More densely populated regions have significantly lower zoning corruption. This is in line with the practice of the audit process in Greece which is initiated and augmented by adjacent property owners' reports. This result highlights the importance of an active - or at least self-interested-citizenry. The findings on the effects of educational attainment and level of population on zoning corruption are mixed. Regional dummies are estimated in reference to Attica, the region of Athens which is the omitted region. This is the most populous region of Greece by far; approximately half of the country's population resides in Attica. This is reflected on zoning corruption counts as well, with the majority of corruption incidences occurring there. 
As a result, all other region dummies compare negatively to Attica. We interpret this as a sheer size effect.

A tabular representation of the housing prices marginal effects is given in Table 7 below.

Table 7: Housing Price Marginal Effects - Greece, 2003-2008

\begin{tabular}{ccc}
\hline & $(1)$ & $(2)$ \\
Housing Prices $\left(€ / m^{2}\right)$ & Contemporaneous & 18 -month Lag \\
\hline 1250 & $0.385^{* *}$ & $0.119^{*}$ \\
& $(0.161)$ & $(0.061)$ \\
1500 & $0.403^{* * *}$ & $0.193^{* * *}$ \\
& $(0.129)$ & $(0.058)$ \\
1750 & $0.421^{* * *}$ & $0.314^{* * *}$ \\
& $(0.093)$ & $(0.028)$ \\
2000 & $0.441^{* * *}$ & $0.510^{* * *}$ \\
& $(0.054)$ & $(0.078)$ \\
2250 & $0.461^{* * *}$ & $0.828^{* * *}$ \\
& $(0.015)$ & $(0.305)$ \\
2500 & $0.483^{* * *}$ & $1.346^{*}$ \\
& $(0.040)$ & $(0.789)$ \\
2750 & $0.505^{* * *}$ & 2.188 \\
& $(0.091)$ & $(1.762)$ \\
\hline Observations & & 702 \\
\hline$* * * p<0.01 ;{ }^{* *} p<0.05 ;{ }^{*} p<0.1$. Standard errors clustered at the regional level (in parentheses)
\end{tabular}

Variation comes in increments of $€ 250$ per square meter, starting from $€ 1500$ up to $€ 3000$ per square meter. We base our results on the lagged housing price specification. Column (2) indicates a wide range of effects. The average predicted monthly corruption count is 0.193 when 18 -month lagged housing prices equaled $€ 1500$ per square meter and the other controls are at their mean values. We estimate as many as 1.3 more cases of zoning corruption per month when housing prices double to $€ 3000$ per square meter. This increasing relationship to housing prices is as expected; zoning corruption increased when profit opportunities became larger. This can also be seen in the graphical representation of the 18-month lagged housing price marginal effects in Figure 8 below.

Figure 8: Lagged Housing Price Marginal Effects, Greece 


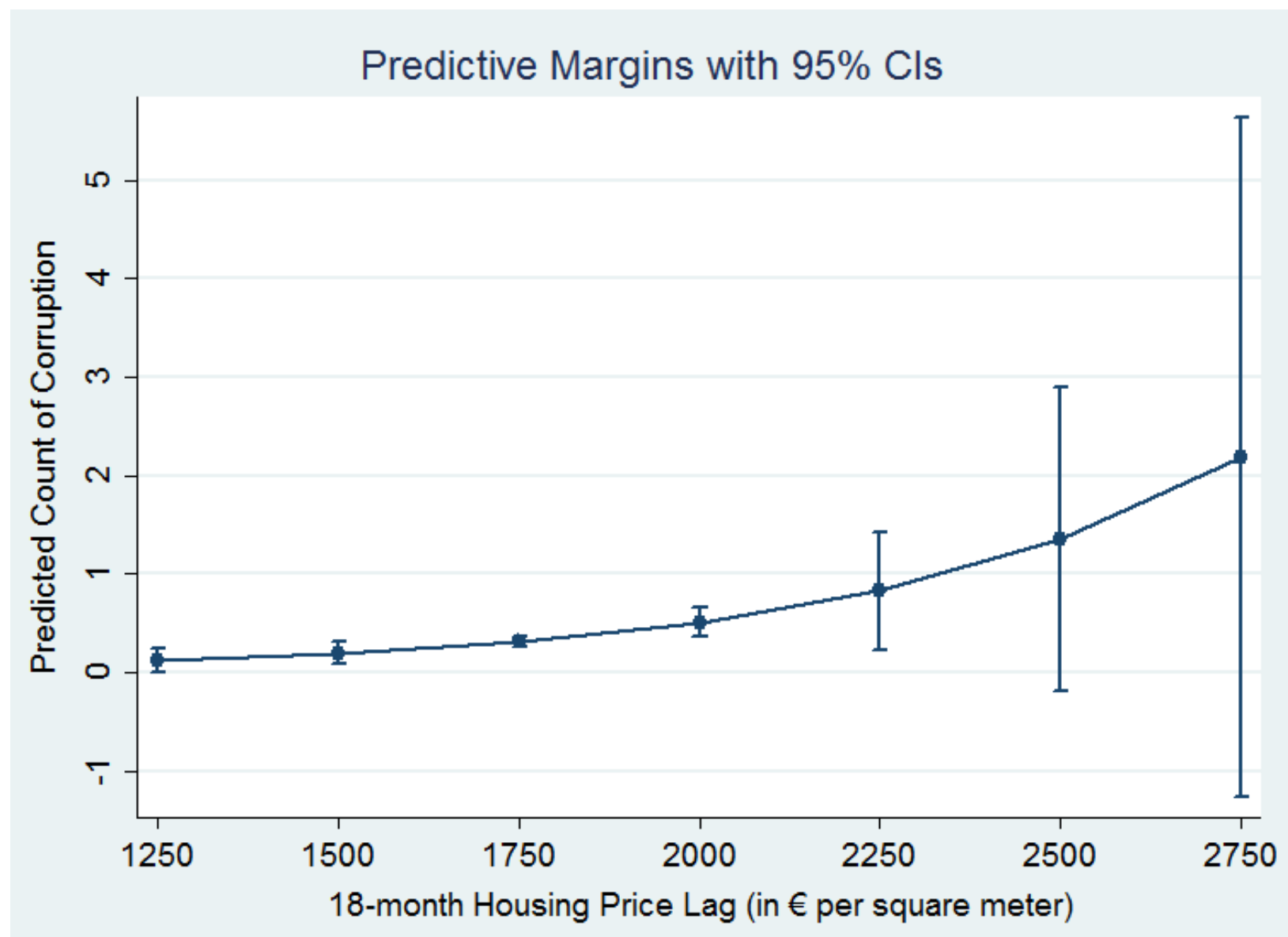

The graph covers a range of housing price values starting from $€ 1250$ through $€ 2750$ per square meter in increments of $€ 100$ per square meter. It is evident from Figure 8 that as housing prices increased, zoning corruption was intensified, as conjectured.

\subsection{The Case of Spain}

First, we discuss the results from the likelihood-ratio test of $\lambda_{i}=0$. The $\chi^{2}$ value of 46.09 suggests that the probability that these observations were generated conditional on $\lambda_{i}=0$ is zero. This implies that the negative binomial model is also far more appropriate than the Poisson model in modeling zoning corruption in Spain.

Table 8 presents parameter estimates of negative binomial regression models for Spain. Again, the focus should be primarily on the signs of the coefficients. Table 9 presents marginal effects that allow us to interpret the magnitudes of the coefficients directly. 


\begin{tabular}{|c|c|c|}
\hline Variables & $\begin{array}{c}(1) \\
\text { Contemporaneous Housing Prices }\end{array}$ & $\begin{array}{c}(2) \\
\text { 6-quarter Housing Price Lag }\end{array}$ \\
\hline Housing Prices $\left(€ / m^{2}\right)$ & $\begin{array}{c}0.00807^{* * *} \\
(0.00167)\end{array}$ & $\begin{array}{l}0.00382^{* * *} \\
(0.000777)\end{array}$ \\
\hline Unemployment & $\begin{array}{l}0.0171 \\
(0.149)\end{array}$ & $\begin{array}{l}0.00179 \\
(0.164)\end{array}$ \\
\hline Population Density & $\begin{array}{l}-0.0107 \\
(0.0185)\end{array}$ & $\begin{array}{c}-0.0386^{*} \\
(0.0200)\end{array}$ \\
\hline Population & $\begin{array}{l}-0.00000006 \\
(0.00000002)\end{array}$ & $\begin{array}{c}0.00000005 \\
(0.00000142)\end{array}$ \\
\hline Education & $\begin{array}{l}0.0696 \\
(0.120)\end{array}$ & $\begin{array}{l}0.0892 \\
(0.116)\end{array}$ \\
\hline Aragon & $\begin{array}{l}-3.471 \\
(13.60)\end{array}$ & $\begin{array}{l}-4.252 \\
(10.01)\end{array}$ \\
\hline Canary Islands & $\begin{array}{c}1.829 \\
(12.99)\end{array}$ & $\begin{array}{c}7.449 \\
(9.886)\end{array}$ \\
\hline Cantabria & $\begin{array}{l}-1.356 \\
(14.66)\end{array}$ & $\begin{array}{l}1.087 \\
(10.51)\end{array}$ \\
\hline Castille-Leon & $\begin{array}{l}-0.411 \\
(11.87)\end{array}$ & $\begin{array}{l}-3.477 \\
(9.243)\end{array}$ \\
\hline Castille-La Mancha & $\begin{array}{l}2.426 \\
(9.554)\end{array}$ & $\begin{array}{l}-0.216 \\
(6.864)\end{array}$ \\
\hline Catalonia & $\begin{array}{l}-5.658 \\
(4.667)\end{array}$ & $\begin{array}{l}1.074 \\
(3.685)\end{array}$ \\
\hline Navarra & $\begin{array}{l}-2.476 \\
(15.42)\end{array}$ & $\begin{array}{l}-3.349 \\
(11.54)\end{array}$ \\
\hline Valencia & $\begin{array}{c}3.736 \\
(7.936)\end{array}$ & $\begin{array}{l}6.615 \\
(6.296)\end{array}$ \\
\hline Madrid & $\begin{array}{l}-4.246 \\
(16.26)\end{array}$ & $\begin{array}{c}19.43 \\
(15.20)\end{array}$ \\
\hline Extremadura & $\begin{array}{c}6.270 \\
(11.20)\end{array}$ & $\begin{array}{c}1.907 \\
(8.293)\end{array}$ \\
\hline Galicia & $\begin{array}{c}0.358 \\
(10.73)\end{array}$ & $\begin{array}{l}-0.311 \\
(8.078)\end{array}$ \\
\hline Balearic Islands & $\begin{array}{l}-1.948 \\
(14.19)\end{array}$ & $\begin{array}{c}5.172 \\
(10.10)\end{array}$ \\
\hline La Rioja & $\begin{array}{c}0.908 \\
(14.46)\end{array}$ & $\begin{array}{l}-0.119 \\
(10.58)\end{array}$ \\
\hline Basque Country & $\begin{array}{l}-8.868 \\
(16.43)\end{array}$ & $\begin{array}{c}2.465 \\
(12.15)\end{array}$ \\
\hline Asturias & $\begin{array}{l}0.0175 \\
(14.51)\end{array}$ & $\begin{array}{c}0.533 \\
(10.81)\end{array}$ \\
\hline Murcia & $\begin{array}{c}1.320 \\
(12.90)\end{array}$ & $\begin{array}{c}2.068 \\
(9.511)\end{array}$ \\
\hline Constant & $\begin{array}{c}-24.64^{* *} \\
(10.11)\end{array}$ & $\begin{array}{c}-15.66^{* *} \\
(7.781)\end{array}$ \\
\hline Observations & 204 & 204 \\
\hline
\end{tabular}

Columns (1) and (2) of Table 8 present the results of specifications using contemporaneous and lagged housing prices, respectively. As for Greece, for Spain we base our findings on the lagged housing prices due to the time-consuming zoning corruption generating process. For a one euro increase in quarterly housing prices, the difference in the logs of expected counts of zoning corruption is expected to increase by 0.00382 units. This relationship is statistically significant at the 1 percent level.

Population density is negatively associated with zoning corruption in Spain. This finding again underscores the importance of civic engagement in curbing zoning corruption. More civilian surveillance can substantially narrow the window of opportunity for zoning corruption.

The estimates of the regional dummies are obtained in reference to Andalucia, which is the most populous and also one of the regions with the highest incidence of zoning corruption scandals in Spain. However, when we adjust for housing prices and other control variables, Andalucia becomes the median region in terms of zoning corruption levels. 
Table 9 below presents marginal effects of housing prices on zoning corruption in Spain.

Table 9: Housing Price Marginal Effects - Spain, 2006-2008

\begin{tabular}{|c|c|c|}
\hline Housing Prices $\left(€ / m^{2}\right)$ & $\begin{array}{c}\text { (1) } \\
\text { Contemporaneous }\end{array}$ & $\begin{array}{c}(2) \\
\text { 18-month Lag }\end{array}$ \\
\hline 750 & $\begin{array}{l}0.012^{*} \\
(0.007)\end{array}$ & $\begin{array}{c}0.038^{* * *} \\
(0.009)\end{array}$ \\
\hline 900 & $\begin{array}{c}0.035^{* * *} \\
(0.012)\end{array}$ & $\begin{array}{c}0.096^{* * *} \\
(0.016)\end{array}$ \\
\hline 1050 & $\begin{array}{l}0.102^{* * *} \\
(0.013)\end{array}$ & $\begin{array}{l}0.241^{* * *} \\
(0.038)\end{array}$ \\
\hline 1200 & $\begin{array}{c}0.303^{* * *} \\
(0.062)\end{array}$ & $\begin{array}{c}0.606^{* * *} \\
(0.122)\end{array}$ \\
\hline 1350 & $\begin{array}{c}0.899^{* * *} \\
(0.395)\end{array}$ & $\begin{array}{c}1.523^{* * *} \\
(0.422)\end{array}$ \\
\hline 1500 & $\begin{array}{c}2.662 \\
(1.822)\end{array}$ & $\begin{array}{l}3.834^{* * *} \\
(1.401)\end{array}$ \\
\hline 1650 & $\begin{array}{c}7.888 \\
(7.352)\end{array}$ & $\begin{array}{l}9.647^{* *} \\
(4.431)\end{array}$ \\
\hline Observations & 204 & 204 \\
\hline
\end{tabular}

To capture the mass of observations, we consider values from $€ 750$ to $€ 1650$ per square meter. The marginal effects of housing prices on zoning corruption are estimated in increments of $€ 150$ per square meter. We base our results on the lagged housing price specification. Again, the marginal effects exhibit a large degree of variation. The average predicted quarterly corruption count is merely 0.038 when lagged housing prices stood at $€ 750$ per square meter but grows exponentially at each housing price increment. The significance of housing prices as a predictor of zoning corruption declines at higher values. This is a consequence of low power at the highest housing price levels. For instance, only four regions ever recorded housing prices greater than $€ 2000$ per square meter (Madrid, Catalonia, the Balearic Islands, and the Basque Country). But even so and similarly to Greece, zoning corruption in Spain was amplified when profit opportunities were heightened. This is also evident in the graphical representation of the housing price marginal effects in Figure 9 below.

Figure 9: Negative Binomial Regression Housing Price Marginal Effects, Spain 


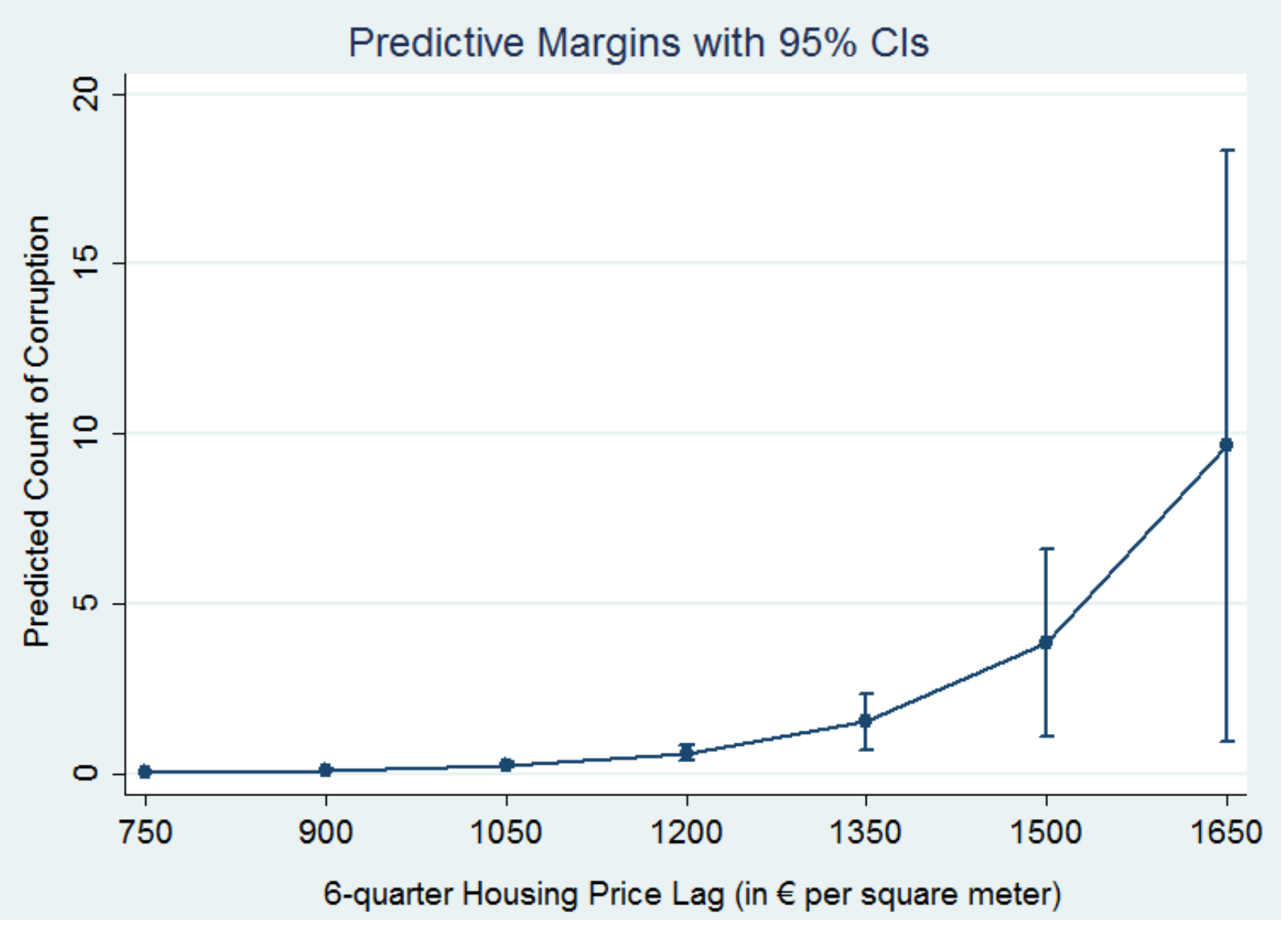

We take a closer look at housing prices and consider values from $€ 750$ per square meter to $€ 1650$ per square meter in increments of $€ 150$ per square meter.

\section{Sensitivity Analysis}

A potential limitation of the analysis is the implementation of inference from a non-random sample. Given the observational nature of our study, selection bias could be present if, for example, zoning corruption is more likely in some regions than others due to unobservable factors. Such constraints that mask the presence of underlying heterogeneity could lead us to erroneous estimates.

The first potential source of bias could come from the presence of omitted variables. Housing prices may have increased faster in regions with higher demand for housing coming from factors that our baseline analysis does not include. For example, coastal regions where tourism is more prominent could have experienced relatively greater price swings possibly because land there yields higher rents. ${ }^{15}$ One would

\footnotetext{
${ }^{15}$ In addition, the majority of new residential properties in Greece and Spain were second homes that were typically erected in coastal areas (summer housing). Also, the percentages of total dwellings occupied by its owner were in both countries among the highest in the EMU. By 2007, the owner-occupancy rates in Greece and Spain were 79.6 percent $\left(4^{\text {th }}\right.$ highest) and 86.3 percent (highest), respectively, when the EMU-average was a mere 62.3 percent (ECB Structural Issues Report, 2009).
} 
expect zoning authorities in these regions to be more susceptible to receiving bribes for unlawful residential construction. To test whether tourism-intensive regions are affected differently by the housing bubbles, we augment the negative binomial model relevant controls. In particular, in order to capture the influence of tourism in the housing stock of a region we adjust our baseline estimates with the number of nights spent at tourist accommodation establishments and the number of bed-places (total number of beds available to tourists) in a region.

The results of the augmented negative binomial regression model are presented in Table 10.

Table 10: Augmented Negative Binomial Regression - Greece, 2003-2008; Spain, 2006-2008

\begin{tabular}{|c|c|c|c|c|}
\hline Variables & $\begin{array}{l}\quad(1) \\
\text { Greece, Lagged } \\
\text { Housing Prices }\end{array}$ & $\begin{array}{c}(2) \\
\text { Greece, Lagged } \\
\text { Housing Prices }\end{array}$ & $\begin{array}{c}(3) \\
\text { Spain, Lagged } \\
\text { Housing Prices }\end{array}$ & $\begin{array}{c}(4) \\
\text { Spain, Lagged } \\
\text { Housing Prices }\end{array}$ \\
\hline Housing Prices $\left(€ / m^{2}\right)$ & $\begin{array}{l}0.002^{* * *} \\
(0.002)\end{array}$ & $\begin{array}{c}0.007^{* * *} \\
(0.008)\end{array}$ & $\begin{array}{c}0.006^{* * *} \\
(0.007)\end{array}$ & $\begin{array}{c}0.005^{* * *} \\
(0.007)\end{array}$ \\
\hline Unemployment & $\begin{array}{c}0.114 \\
(0.254)\end{array}$ & $\begin{array}{c}0.151 \\
(0.249)\end{array}$ & $\begin{array}{l}-0.107 \\
(0.097)\end{array}$ & $\begin{array}{l}-0.042 \\
(0.093)\end{array}$ \\
\hline Population Density & $\begin{array}{c}-0.098^{* * *} \\
(0.031)\end{array}$ & $\begin{array}{c}-0.081^{* * * *} \\
(0.021)\end{array}$ & $\begin{array}{l}-0.045 \\
(0.032)\end{array}$ & $\begin{array}{l}-0.048 \\
(0.032)\end{array}$ \\
\hline Population & $\begin{array}{l}-0.000104 \\
(0.000092)\end{array}$ & $\begin{array}{l}-0.000044 \\
(0.000046)\end{array}$ & $\begin{array}{l}-0.000004 \\
(0.000003)\end{array}$ & $\begin{array}{l}-0.000004 \\
(0.000003)\end{array}$ \\
\hline Education & $\begin{array}{c}0.00844 \\
(0.189)\end{array}$ & $\begin{array}{c}-0.0289 \\
(0.175)\end{array}$ & $\begin{array}{c}0.153 \\
(0.119)\end{array}$ & $\begin{array}{c}0.132 \\
(0.110)\end{array}$ \\
\hline Tourist Bed-Places & $\begin{array}{c}0.000085 \\
(0.000104)\end{array}$ & & $\begin{array}{c}0.000007 \\
(0.000008)\end{array}$ & \\
\hline Tourist Nights Spent & & $\begin{array}{l}-0.000022 \\
(0.000029)\end{array}$ & & $\begin{array}{c}0.0000003 \\
(0.0000001)\end{array}$ \\
\hline $\begin{array}{l}\text { Regional Dummies } \\
\text { Constant }\end{array}$ & $\begin{array}{c}\text { YES } \\
245.9 \\
(371.1)\end{array}$ & $\begin{array}{c}\text { YES } \\
253.5 \\
(179.7)\end{array}$ & $\begin{array}{c}\text { YES } \\
-23.475^{\text {**** }} \\
(5.675)\end{array}$ & $\begin{array}{c}\text { YES } \\
-33.01^{* * *} \\
(10.39)\end{array}$ \\
\hline Observations & 702 & 702 & 204 & 204 \\
\hline
\end{tabular}

${ }^{* * *} p<0.01 ;{ }^{* *} p<0.05 ;{ }^{*} p<0.1$. Standard errors clustered at the regional level (in parentheses)

The positive and statistically significant relationship between housing prices and zoning corruption is robust to the inclusion of the tourism intensity controls. The variables 'nights spent at tourist accommodation establishments' and the 'number of bed-places in a region' are not significant predictors of zoning corruption. 
The second robustness check tests whether the baseline modeling of zero values is mis-specified. The zero-inflated negative binomial (ZINB) model may be more appropriate when modeling count data with a significant number of zeros. As mentioned above, our time series for zoning corruption events in Greece and Spain contain many zero values. Lambert (1992) and Greene (1994) suggest that excess zeros may be generated by a separate process from the count values and models them independently using a logit model for predicting excess zeros. Here we use issued construction permits as the predictor of the number of zero zoning corruption cases in a region. Intuitively, the window of opportunity to engage in corrupt acts should be greater when more construction activity is present.

To formally test for model misspecification, we conduct the Vuong test to determine whether a ZINB versus a negative binomial model should be specified (Vuong, 1989). In essence, we check whether the presence of a zero was actually true or is simply due to misspecification. This test statistic has a standard normal distribution with large positive values favoring the ZINB model, large negative values favoring the negative binomial one, and with values close to zero favoring neither model (Long, 1997). In the case of Greece, the Vuong test's z-values when modeling contemporaneous and lagged housing prices are 0.67 and 5.85, respectively. For the model of contemporaneous and lagged housing prices in Spain the test's zvalue are equal to .25 and 0.23 , respectively. As a result, we cannot discard the earlier results in favor of the ZINB models but still provide results from the latter as a supplement.

Columns (1) and (2) of Table 11 below present estimates of the ZINB models for Greece and Spain, respectively. We only present results for our baseline specifications that use lagged housing prices. 
(1)

$(2)$

\begin{tabular}{lcc} 
Variables & Greece, Lagged Housing Prices & Spain, Lagged Housing Prices \\
\hline Housing Prices $\left(€ / m^{2}\right)$ & $0.00122^{* *}$ & $0.00623^{* * *}$ \\
& $(0.000510)$ & $(0.00065)$ \\
Unemployment & 0.133 & -0.102 \\
& $(0.167)$ & $(0.082)$ \\
Population Density & $-0.0713^{* * *}$ & $-0.0533^{* *}$ \\
& $(0.0151)$ & $(0.0246)$ \\
Inflate(Population) & -0.000038 & $-0.0000017^{* *}$ \\
& $(0.000037)$ & $(0.00000007)$ \\
Education & -0.0433 & 0.1062 \\
& $(0.134)$ & $(0.1156)$ \\
Regional Dummies & YES & YES \\
Constant & 501.6 & -6.997 \\
& $(371.1)$ & $(5.096)$ \\
\hline Observations & 702 & 204 \\
\hline$* * *$ & $p<0.01 ; * *<0.05 ; * p<0.1$. Standard errors clustered at the regional level (in parentheses). Population \\
specified as the inflated variable. & &
\end{tabular}

The positive and statistically significant relationship between housing prices and zoning corruption is robust to the specification of a zero-inflated model as well. The results of this robustness check suggest that the baseline modeling of the zero-dominated corruption generating process is adequate. With respect to housing prices, the ZINB model for Greece yields very similar estimates to the baseline model whereas for Spain it indicates our baseline estimates are, if anything, conservative.

In our third robustness check, we ponder a necessary assumption of our baseline model. The foundation for the negative binomial model is the Poisson distribution. It comes from the family of exponential distributions and exhibits a "memoryless property". It depends on key assumptions regarding independence, stationarity, and homogeneity (Cameron and Trivedi, 1998, pp.5-8). However, when modeling individual-level, sequential behavioral choices these assumptions may be potentially violated. In our case, it is unlikely that zoning corruption events took place independently of former levels of corruption. In general, corruption is not "memoryless". Bribes are offered because of the prevailing culture of bribery-prone zoning activity (for example, regarded as the most corrupt branch of the Greek bureaucracy). Such cultural stylized facts are certainly not formed overnight. If bribing a zoning official was a phenomenon alien to Greek and Spanish societies, then the increase in profit opportunities might not have prompted the corrupt behavioral responses we find. Also, Andvig and Moene (1990) argue that "corruption may corrupt" since the profitability of corruption may be related to its frequency. This would violate the independence assumption, a fundamental Poisson postulate, and put into question our baseline estimates from the negative binomial model. This motivates the robustness check involving linear OLS 
regression (Mroz, 2012). More specifically, to test whether our results are robust to relaxing the "memoryless" property in the manner zoning corruption events arise, we estimate linear regression models. We re-parameterize zoning corruption to a continuous variable because count data fit linear models poorly. The dependent variable now expresses zoning corruption per 100,000 individuals. The results are shown in Table 12 below.

Table 11: Linear Regression - Greece, 2003-2008; Spain, 2006-2008

\begin{tabular}{lcc}
\hline & $(1)$ & $(2)$ \\
Variables & Greece, Lagged Housing Prices & Spain, Lagged Housing Prices \\
\hline Housing Prices $\left(€ / m^{2}\right)$ & $0.000380^{*}$ & $0.00265^{*}$ \\
& $(0.000203)$ & $(0.001475)$ \\
Unemployment & 0.0275 & -0.1431 \\
& $(0.0190)$ & $(0.2830)$ \\
Population Density & $-0.0682^{* * *}$ & $-0.1149^{*}$ \\
& $(0.00686)$ & $(0.0614)$ \\
Population & -0.0000065 & $0.000014^{*}$ \\
& $(0.0000082)$ & $(0.0000007)$ \\
Education & -0.0135 & $0.1402^{*}$ \\
& $(0.0228)$ & $(0.07603)$ \\
Regional Dummies & YES & YES \\
Constant & $98.42^{* *}$ & $-101.84^{*}$ \\
& $(37.06)$ & $(52.26)$ \\
\hline Observations & 702 & 204 \\
R-squared & 0.625 & 0.401 \\
\hline
\end{tabular}

${ }^{* * *} p<0.01 ;{ }^{* *} p<0.05 ;^{*} p<0.1$. Standard errors clustered at the regional level (in parentheses).

Columns (1) and (2) present estimates from the lagged housing price specification for Greece and Spain, respectively. Our baseline results are robust to the linear specification. We report a positive and significant association between housing prices and zoning corruption. Figures 10 and 11 use binned scatterplots ("binscatters") to provide a graphical representation of the OLS estimates for Greece and Spain, respectively.

Figure 10: Graphical Representation of OLS Estimates for Greece using a Binscatter 


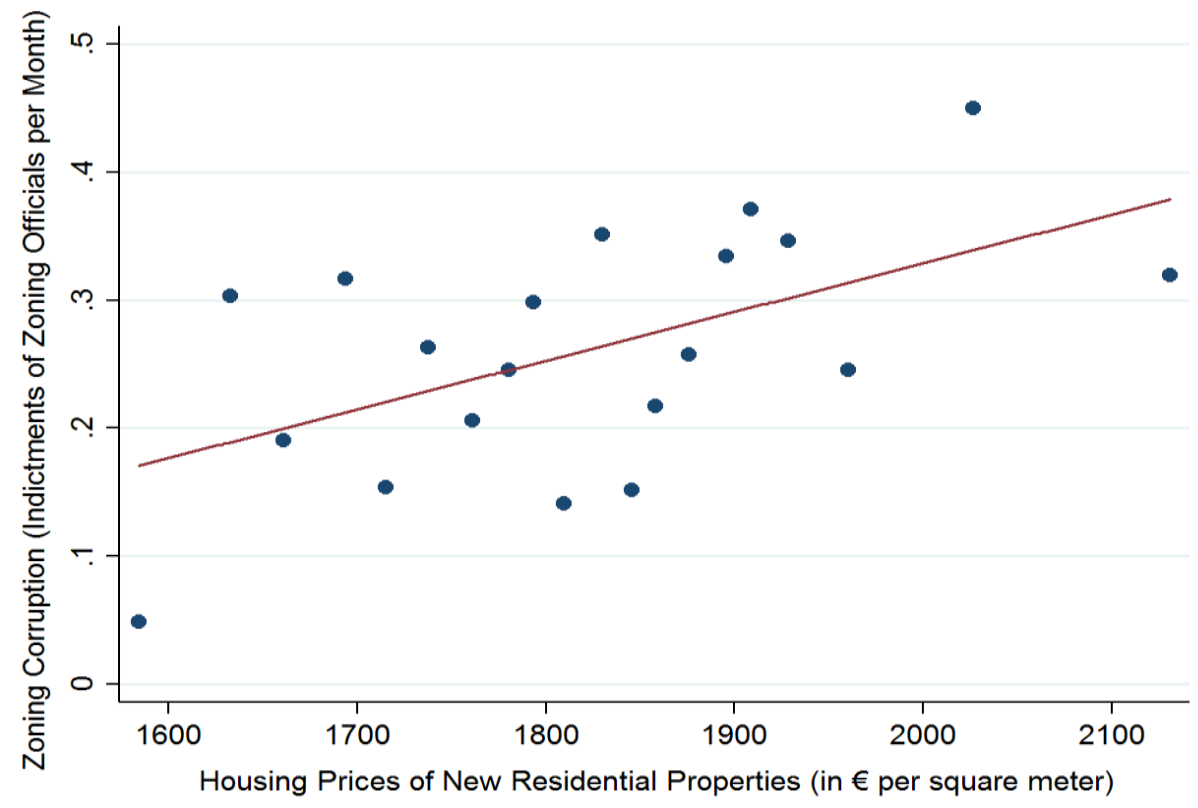

Figure 11: Graphical Representation of OLS Estimates for Spain using a Binscatter

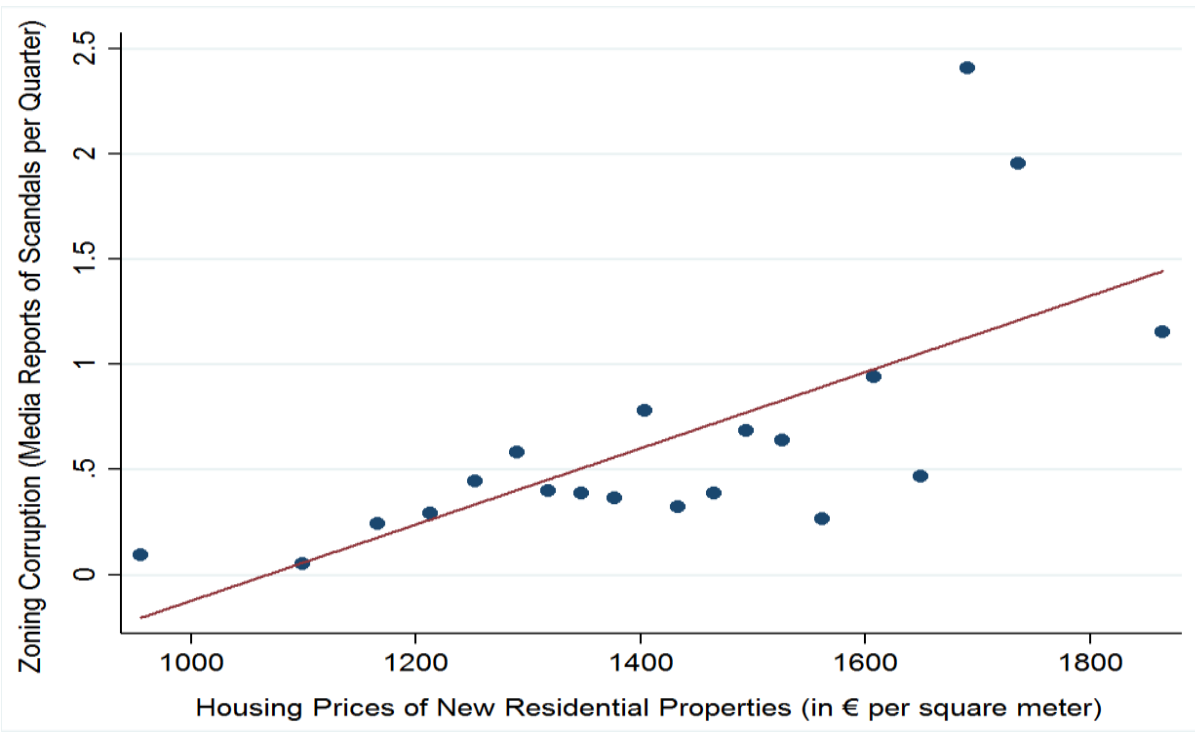

Graphically, it is clear that as housing prices increased, zoning corruption was amplified. The "binscatters" also indicate that this relationship is more significant in the case of Spain, in a statistical manner. Our baseline results are robust even when we assume away the "memoryless property" in the incidence of zoning corruption.

In our fourth robustness check, we employ Generalized Method of Moments (GMM) estimators to explore the importance of "dynamic panel bias". As previously mentioned, this is a plausible assumption because zoning corruption may not be independent over time. If current values are related to their own past realizations, lagged values of zoning corruption should be used as explanatory variables. Then, OLS 
estimates are subject to "dynamic panel bias" because lagged values of zoning corruption are endogenous to the fixed effect in the error term (Roodman, 2006). However, if $\mathrm{T}$ is large, dynamic panel bias becomes insignificant, and the OLS estimates are reliable. Also, GMM estimators permit independent variables that are not strictly exogenous, meaning correlated with past and possibly current realizations of the error. We can test the robustness of our results under the assumption that housing prices are endogenous to zoning corruption. Given the observational nature of our study, this allows us to assess the causal interpretation of the housing price coefficient of our baseline results.

Since GMM estimators assume a linear functional relationship, we use zoning corruption per 100,000 individuals, a continuous dependent variable. We take first differences to eliminate unobserved regionspecific fixed effects and use lagged instruments to correct for simultaneity in the first-differenced equations (Arellano and Bond, 1991). This yields the difference GMM estimator. However, if the dependent variable follows approximately a random walk, then this estimator will perform poorly. Specifically, past levels of zoning corruption will not be informant of future changes and, therefore, untransformed lags will be weak instruments for transformed variables (Roodman, 2006). To increase efficiency, we difference the instruments to make them exogenous to the fixed effects (Arellano and Bover, 1995; Blundell and Bond, 1998). This system GMM estimator will be valid assuming that differences in any instrumenting variables are uncorrelated with the fixed effects. The system GMM estimator is superior to the difference GMM in terms of root mean squared error. However, the latter is important primarily for prediction, in which the negative binomial model does already an excellent job as Figure 6 and 7 indicate. Bun and Windmeijer (2010) show that the 2SLS biases can be greater than the OLS biases in finite samples due to a weak instruments problem. Therefore, we employ both the two-step difference GMM and the two-step system GMM estimators with robust standard errors and small-sample adjustments (Windmeijer, 2000).

GMM estimators are designed for panels with few time periods (T) and a large number of cross-sectional units $(\mathrm{N})$. Generally, the instrument count should not exceed the number of regions because as $\mathrm{T}$ increases the number of instrumenting variables tends to explode and the Arellano-Bond autocorrelation test becomes imprecise (Roodman, 2006). To conform with this rule of thumb, we collapse the panel of Greece to annual frequency ( 7 time periods) and the panel of Spain in semi-annual frequency ( 6 time periods) and do not make extensive use of lags as instruments. Autocorrelation is not a concern in any of the specifications according to the Arelland-Bond test for an $\mathrm{AR}(1)$ and $\mathrm{AR}(2)$ in the first differences of the lagged instruments. Table 12 below shows the results of the two-step system GMM estimations for Greece and Spain, collectively. 
Table 12: GMM Estimation of Dynamic Panel Model - Greece, 2003-2008, annual; Spain, 2006-2008, semi-annual

\begin{tabular}{|c|c|c|c|c|}
\hline Variables & $\begin{array}{c}(1) \\
\text { Greece, Baseline }\end{array}$ & $\begin{array}{c}(2) \\
\text { Greece, System } \\
\text { GMM }\end{array}$ & $\begin{array}{c}(3) \\
\text { Spain, Difference } \\
\text { GMM }\end{array}$ & $\begin{array}{c}(4) \\
\text { Spain, System } \\
\text { GMM }\end{array}$ \\
\hline Corruption Rate per 100k, 1-Year Lag & $\begin{array}{l}-0.2744518 \\
(0.1085221)\end{array}$ & $\begin{array}{c}-0.215224 \\
(0.2141529)\end{array}$ & $\begin{array}{l}-0.2110873 \\
(0.2257008)\end{array}$ & $\begin{array}{c}0.0984775^{*} \\
(0.0506335)\end{array}$ \\
\hline Housing Prices & $\begin{array}{c}0.0001923 \\
(0.0003862)\end{array}$ & $\begin{array}{c}0.0006047 \\
(0.0003569)\end{array}$ & $\begin{array}{l}0.0021948^{*} \\
(0.0010582)\end{array}$ & $\begin{array}{c}0.0001186^{* * *} \\
(0.0000289)\end{array}$ \\
\hline Unemployment & & & $\begin{array}{l}-0.2563092 \\
(0.1831954)\end{array}$ & \\
\hline Density & $\begin{array}{l}-0.0266624 \\
(0.0246729)\end{array}$ & & $\begin{array}{l}-0.0135126 \\
(0.0157812)\end{array}$ & $\begin{array}{c}-0.0003502^{* *} \\
(0.0001322)\end{array}$ \\
\hline Education & $\begin{array}{l}-0.0078916 \\
(0.0509265)\end{array}$ & & $\begin{array}{l}0.0517698 \\
(0.073579)\end{array}$ & \\
\hline Constant & & $\begin{array}{l}-0.5610423 \\
(0.6461527)\end{array}$ & & \\
\hline Number of Regions & 13 & 13 & 17 & 17 \\
\hline Number of Instruments & 10 & 13 & 10 & 17 \\
\hline AR(1) in First Differences & $\operatorname{Pr}>z=0.285$ & $\operatorname{Pr}>z=0.272$ & $\operatorname{Pr}>z=0.088$ & $\operatorname{Pr}>z=0.018$ \\
\hline $\mathrm{AR}(2)$ in First Differences & $\operatorname{Pr}>z=0.611$ & $\operatorname{Pr}>z=0.515$ & $\operatorname{Pr}>z=0.593$ & $\operatorname{Pr}>z=0.095$ \\
\hline Hansen Test of Overidentification Restrictions & $\operatorname{Pr}>\chi^{2}=0.455$ & $\operatorname{Pr}>\chi^{2}=0.328$ & $\operatorname{Pr}>\chi^{2}=0.142$ & $\operatorname{Pr}>\chi^{2}=0.272$ \\
\hline
\end{tabular}

Column (1) shows the estimates of a specification for Greece where zoning corruption is endogenous in time, housing prices are endogenous, and augmented by density and education as IV-style instruments. The coefficient of housing prices in column (1) is positive but not statistically significant. The rule of thumb is preserved and we do not overidentify using few instruments. Still, the latter are not particularly strong as the Hansen test indicates. Column (2) shows the estimates of a specification for Greece where zoning corruption is endogenous in time, housing prices are not strictly exogenous, and only year dummies serve as additional instruments. The coefficient of housing prices is positive and almost significant at the 10 percent level. The estimates in column (2) are more reliable since the instruments are stronger and the instrument count does not exceed the number of regions in Greece. When we introduce more controls (e.g. population density or educational level) the relationship of interest does turn significant. However, this comes at the expense of instrument power as the instrument count then exceeds the number of regions in Greece. We refrain from violating this minimal rule of thumb of GMM estimation but note that the positive and significant relationship between zoning corruption and housing prices virtually holds.

Column (3) presents the difference GMM estimates for Spain. We specify zoning corruption to be endogenous in time, and housing prices as an endogenous regressor. We use density and education as instruments from the baseline controls. Unemployment is considered predetermined but not strictly 
exogenous because its inclusion in the instrument pool severely reduces the instruments' strength. The instrument count in this specification is well below the number of regions and, as a result, this set of instruments is the strongest among all estimations. Accounting for any dynamic panel bias, we retrieve a positive and statistically significant relationship between housing prices and zoning corruption. Column (4) shows the estimates of the system GMM estimator for Spain where zoning corruption is endogenous in time, housing prices are treated as an endogenous regressor, and only population density is added as an instrument. The coefficient of housing prices is positive and very significant. The instrument count in this estimation is just equal to the number of regions and, as a result, density is not a weak instrument ${ }^{16}$. The Arellano-Bond tests show that autocorrelation is only minor.

The GMM estimates suggest that our baseline results are fairly robust to dynamic panel bias, even when the panels are collapsed to fewer time units. The first takeaway is that the positive association between zoning corruption and housing prices is preserved. Second, even if housing prices are assumed to be endogenous, results do not change substantially. The statistical significance in the case of Greece dissipates when parameters are estimated using the annual panel. However, any dynamic panel bias should be negligible in the longer, monthly panel that served as the basis for estimation of the negative binomial and earlier linear models. Thus, we cannot interpret the insignificant coefficient as evidence against our baseline results for Greece. The positive and statistically significant relationship between zoning corruption and housing prices in Spain is robust to the GMM estimations. This is encouraging for the validity of our baseline findings because the "small T, large N" panel for Spain might have leaked dynamic panel bias in those estimates. Clearly, GMM estimators are more enlightening in the case of Spain $(\mathrm{T}=12, \mathrm{~N}=17)$ whereas the fixed effects estimator is more fitting for the baseline panel of Greece $(\mathrm{T}=72, \mathrm{~N}=13) .{ }^{17}$

Finally, we conduct two country-specific robustness checks that address potential measurement error.

In the case of Greece, we explore whether our results are subject to measurement error of the housing price information. Recall that the housing price observations are the result of our interaction of national time series with local cross-sections of housing prices. Here, we consider a sub-sample of Greek regions for which the official housing price information matches our geographical disaggregation perfectly. ${ }^{18}$ Our

\footnotetext{
${ }^{16}$ Note that we drop the constant from the system GMM estimation to achieve equal instrument counts to regions.

${ }^{17}$ The unconditional negative binomial model is susceptible to a potential parameters problem which there is no way to explore. When using the dummy variable approach, estimates of negative binomial models in short panels might be inconsistent due to the incidental parameters problem (Cameron and Trivedi, 1998, p.282). These perform well for sample size of at least 200 observations, a sample size requirement met only marginally in the panel for Spain. In light of potentially inconsistent baseline estimates for Spain, the system GMM estimates for Spain become even more important.

${ }^{18}$ These are the regions of Attica and Central Macedonia that account for more than 50 percent of the country's population and include the mass of corruption counts.
} 
baseline findings are robust. To preserve space, estimates are not shown. Even in this restricted sample, the positive relationship between zoning corruption and housing prices persists.

In the case of Spain, we conduct a sensitivity analysis of our findings across all methods employed by introducing deeper geographical disaggregation. We employ information at the provincial level (Eurostat NUTS-level 3), a more local level of governance relative to the regional level (Eurostat NUTS-level 2). Specifically, the number of cross-sectional units almost triples from 17 to 50 . As a result, we are able to exploit substantially more cross-sectional variation in the identification of model parameters. Moreover, this geographical disaggregation makes the causal relationship between housing prices and zoning corruption more tenable. By design, the use of smaller geographical units reduces the measurement error in the association of an instance of zoning corruption with a particular housing price level. The natural mapping of zoning corruption to housing becomes less crude by almost $300 \%$.

Data limitations prevent us from carrying out a similar geographical robustness check for Greece as zoning corruption information is available only at the regional level.

Table 13 below revisits our findings from count data models using provincial-level information. Specifically, columns (1) and (2) present results for the negative binomial and zero-inflated model regressions for housing price in levels. Column (3) replicates our baseline negative binomial model of lagged housing prices, whereas in column (4) we implement its zero-inflated variant. Note that the set of controls varied slightly relative to the regional analysis. The Eurostat does not provide a wealth of provincial information (NUTS level 3) which severely restricts our choice of control variables. As a result, we use GDP level per capita in the place of education and unemployment rate to proxy the level of development in the province. We maintain population density as a control variable and use population as the exposure variable.

Table 13: Count Data Models - Spanish Provinces 


\begin{tabular}{lcccc}
\hline & $(1)$ & $(2)$ & $(3)$ & $(4)$ \\
Variables & Neg Bin & Lag Neg Bin & Zero-inflated & Lag Zero-inflated \\
\hline Housing Prices & $0.00636^{* * *}$ & $0.00640^{* * *}$ & & \\
& $(0.00161)$ & $(0.00142)$ & & \\
6-quarter Housing Price Lag & & & $0.00165^{*}$ & $0.00175^{*}$ \\
Density & & & $(0.00090)$ & $(0.00090)$ \\
& -0.00677 & -0.00674 & -0.00626 & -0.00598 \\
GDP per capita & $(0.00568)$ & $(0.00910)$ & $(0.00831)$ & $(0.00944)$ \\
& $0.00036^{* *}$ & $0.00038^{* *}$ & $0.00050^{* * *}$ & $0.00050^{* * *}$ \\
Constant & $(0.00014)$ & $(0.00016)$ & $(0.00016)$ & $(0.00019)$ \\
& $-30.00345^{* * *}$ & $-16.51667^{* * *}$ & $-25.59613^{* * *}$ & $-11.86371^{* * *}$ \\
Number of Regions & $(2.68045)$ & $(2.67890)$ & $(3.09566)$ & $(3.28132)$ \\
\hline
\end{tabular}

${ }^{* * *} p<0.01 ;{ }^{* *} p<0.05 ;{ }^{*} p<0.1$. Standard errors clustered at the provincial level in columns (1), (2)

The positive and statistically significant relationship between zoning corruption and housing prices persists at the provincial panel. We do not report any substantial differences between the negative binomial models and their zero-inflated counterparts. This is due to the fact that the two specifications are not different at all as the Vuong test statistic indicates. Specifically, with a value of 0.06 and 0 for the contemporaneous and lagged specifications, the two models are virtually the same.

Next, using the provincial panel we estimate linear models where the dependent variable takes the form of a rate: zoning corruption per 100,000 individuals. It should be noted that the increased cross-sectional variation naturally leads to a substantial improvement in our estimates obtained via panel methods. This is particularly true for the GMM models that are ideal for "small T, large N" panels. Thus, the findings of the following fixed effects and dynamic panel models in Table 14 are preferable to the ones for Spain in Table 11 and 12.

Table 14: Linear Models - Spanish Provinces 


\begin{tabular}{|c|c|c|c|c|}
\hline Variables & $\begin{array}{c}(1) \\
\text { Contemporaneous } \\
\text { FE }\end{array}$ & $\begin{array}{c}(2) \\
\text { Lagged FE }\end{array}$ & $\begin{array}{c}(3) \\
\text { Difference GMM }\end{array}$ & $\begin{array}{c}(4) \\
\text { System GMM }\end{array}$ \\
\hline Corruption Rate per 100k, 1-Year Lag & & & $\begin{array}{c}0.00557 \\
(0.09217)\end{array}$ & $\begin{array}{l}0.00557^{* *} \\
(0.03273)\end{array}$ \\
\hline Housing Prices & $\begin{array}{c}0.00044^{* * *} \\
(0.00016)\end{array}$ & $\begin{array}{l}0.00018^{*} \\
(0.00010)\end{array}$ & $\begin{array}{c}0.00345 \\
(0.00332)\end{array}$ & $\begin{array}{l}0.00022^{*} \\
(0.00012)\end{array}$ \\
\hline GDP per capita & $\begin{array}{l}0.000028^{* *} \\
(0.000012)\end{array}$ & $\begin{array}{l}0.000029^{* *} \\
(0.000011)\end{array}$ & $\begin{array}{c}0.000104 \\
(0.000100)\end{array}$ & $\begin{array}{c}-0.000014^{* * *} \\
(0.000005)\end{array}$ \\
\hline Density & $\begin{array}{c}-0.00083^{* *} \\
(0.00032)\end{array}$ & $\begin{array}{c}-0.00045^{*} \\
(0.00025)\end{array}$ & $\begin{array}{l}-0.00168 \\
(0.00131)\end{array}$ & $\begin{array}{c}-0.00044^{*} \\
(0.00022)\end{array}$ \\
\hline Population & $\begin{array}{c}0.00000004 \\
(0.00000022)\end{array}$ & $\begin{array}{c}-0.00000016 \\
(0.00000028)\end{array}$ & $\begin{array}{l}-0.00000029 \\
(0.00000094)\end{array}$ & \\
\hline Constant & $\begin{array}{c}-1.19204186^{* * *} \\
(0.21568277)\end{array}$ & $\begin{array}{c}-0.62168329^{* *} \\
(0.24577716)\end{array}$ & & \\
\hline Number of Regions & 50 & 50 & 50 & 50 \\
\hline Number of Instruments & 0 & 0 & 23 & 43 \\
\hline $\mathrm{AR}(1)$ in First Differences & & & $\operatorname{Pr}>z=0.003$ & $\operatorname{Pr}>z=0.001$ \\
\hline $\mathrm{AR}(2)$ in First Differences & & & $\operatorname{Pr}>z=0.386$ & $\operatorname{Pr}>z=0.332$ \\
\hline Hansen Test of Overidentification Restrictions & & & $\operatorname{Pr}>\chi^{2}=0.545$ & $\operatorname{Pr}>\chi^{2}=0.579$ \\
\hline
\end{tabular}

Again, our results from the linear models are insensitive to the geographical disaggregation of the zoning corruption and housing price information. We recover a positive and statistically significant result between the two in columns (1), (2) and (4). Controlling for unobservable characteristics that are unique to a province, we show that both contemporaneous and lagged housing prices substantially increase zoning corruption. The dynamic panel methods in columns (3) and (4) address serial correlation. The coefficient of housing prices becomes insignificant for the difference GMM estimator that relies primarily on corruption lags. However, when we improve GMM estimation by also exploiting controls as instruments we are able to replicate the earlier system GMM results for Spain.

Overall, the robustness of our baseline results to the use of provincial information indicates they are not subject to significant error in space in the measurement and attachment of zoning corruption to local housing prices.

\section{Concluding remarks}

The understanding of the determinants of corruption and its effects on the economy is a fast-growing field of study in public and urban economics. We follow an emerging literature of the empirical studies of corruption that exploits shocks to corruption incentives brought about by nature or by policy. We use the adoption of the euro and its associated windfall of cheap mortgage credit in Greece and Spain to examine the effect of housing price bubbles on zoning corruption. The increased supply of loanable funds at 
cheaper rates helped expand economic activity for a decade but also postponed important structural reforms. The latter had significant side effects that became imminent years later.

The empirical analysis relies on objective measures of zoning corruption in Greece and Spain, measured at the regional level. We estimate negative binomial models and test the robustness of our findings using zero-inflated and linear regression models. We document a positive and significant relationship between housing prices and zoning corruption. The positive association is robust to a series of checks that include zero-inflated variants of the negative binomial model, and linear models that address model misspecification, omitted variable and dynamic panel bias. 


\section{References}

Aidt, T. (2003). Economic Analysis of Corruption. The Economic Journal, 632-652.

Allison, P., and Waterman, R. (2002). Fixed-Effects Negative Binomial Regression Models. Sociological Methodology, $247-265$.

Alternativas, F. (2007). Urbanismo y democracia. Alternativas para evitar la corrupcion. Madrid: Fundacion Alternativas.

Andvig, J., and Moene, K. O. (1990). How Corruption May Corrupt. Journal of Economic Behavior and Organization, 63-76.

Arellano, M., and Bond, S. (1991). Some Tests of Specification for Panel Data: Monte Carlo Evidence and an Application to Employment Equations. Review of Economic Studies, 277-297.

Arellano, M., and Bover, O. (1995). Another look at the instrumental variable estimation of error-components models. Journal of Econometrics, 29-51.

Bank of Spain. (2013). MORTGAGE LOAN ACCESS GUIDE. Madrid: Bank of Spain.

Batzilis, D. (2014). Does Electoral Competition Reduce Corruption? Evidence from Municipality Audits in Greece. Chicago: University of Chicage PhD Dissertation.

Baum, C. (2001). Stata: The language of choice for time series analysis? The Stata Journal, 1-16.

Becker, G. S. (1968). Crime and Punishment: An Economic Approach. Journal of Political Economy, 169-217.

Beets, D. (2005). Understanding the Demand-Side Issues of International Corruption. Journal of Business Ethics, 65-81.

Bliss, C., and Di Tella, R. (1997). Does Competition Kill Corruption? Journal of Political Economy, 1001-1023.

Blundell, R., and Bond, S. (1998). Initial Conditions and Moment Restrictions in Dynamic Panel Data Models. Journal of Econometrics, 115-143.

Braun, M., and Di Tella, R. (2004). Inflation, Inflation Variability, and Corruption. Economics and Politics, 77-100.

Brissimis, S., and Vlassopoulos, T. (2007). The Interaction Between Mortgage Financing and Housing Prices in Greece. Bank of Greece Working Paper.

Brollo, F., Nannicini, T., Perotti, R., and Tabellini, G. (2013). The Political Resource Curse. American Economic Review, 17591796.

Bujko, M., Fischer, C., Krieger, T., and Meierrieks, D. (2015). How Institutions Shape Land Deals: The Role of Corruption. CESIFO WORKING PAPER NO. 5178.

Bun, M. J., and Windmeijer, F. (2010). The weak instrument problem of the system GMM estimator in dynamic panel data models. The Econometrics Journal, 95-126.

Cameron, C., and Trivedi, P. (2005). Microeconometrics: Methods and Applications. Cambridge: Cambridge University Press.

Caselli, F., and Michaels, G. (2013). Do Oil Windfalls Improve Living Standards? Evidence from Brazil. American Economic Journal: Applied Economics, 208-38.

Chang, H.-J. (2010). Institutions and Economic Development: Theory, Policy and History. Journal of Institutional Economics, 125 .

Cheung, H. Y., and Chan, A. (2008). Corruption Across Countries; Impacts from Education and Cultural Dimensions. The Social Science Journal, 223-239.

Clemente, J., Montanes, A., and Reyes, M. (1998). Testing for a unit root in variables with a double change in the mean. . Economic Letters, 175-182.

Costas-Pérez, E., Solé-Ollé, A., and Sorribas-Navarro, P. (2013). Corruption scandals, voter information, and accountability. European Journal of Political Economy, 469-484. 
Del Monte, A., and Papagni, E. (2007). The determinants of corruption in Italy: Regional panel data analysis. European Journal of Political Economy, 379-396.

Dong, B., and Torgler, B. (2013). Causes of Corruption: Evidence from China. China Economic Review, 152-169.

ECB Structural Issues Report. (2009). Housing Finance in the Euro Area. Frankfurt: European Central Bank.

El Bahnasawy, N., and Revier, D. (2012). The determinants of corruption: Cross-Country-Panel-Data Analysis. The Developing Economies, pp. 311-333.

Emerson, P. (2006). Corruption, Competition and Democracy. Journal of Development Economics, 193-212.

Fernández-Villaverde, J., Garicano, L., and Santos, T. (2013). Political Credit Cycles: The Case of the Eurozone. Journal of Economic Perspectives, 145-166.

Ferraz, C., and Finan, F. (2009). Electoral Accountability and Corruption: Evidence from the Audits of Local Governments. NBER Working Paper Series.

Frechette, G. R. (2001). A Panel Data Analyis of the Time-Varying Determinants of Corruption. EPCS Conference Proceedings.

Gentier, A. (2012). Spanish Banks and the Housing Crisis: Worse than the Subprime Crisis? International Journal of Business, 343-351.

Gimeno, R., and Martínez-Carrascal, C. (2006). L ainteracción entre el precio de la vivienda y el crédito a hogares destinado a su adquisición. Boletín Económico.

Glaeser, E. L., Gyourko, J., and Saiz, A. (2008). Housing Supply and Housing Bubbles. Journal of Urban Economics, 198-217.

Golden, M. (2015). A Global View of Political Corruption. Barcelona: Institut d' Economia de Barcelona.

Himoniti-Terroviti, S. (2005). Recent developments in the Greek housing market. Athens: Centre of Planning and Economic Research Report No. 43.

Holt, J. (2009). A Summary of the Primary Causes of the Housing Bubble and the Resulting Credit Crisis: A Non-Technical Paper. The Journal of Business Inquiry, 120-129.

Husted, B. W. (1999). Wealth, Culture, and Corruption. Journal of International Business, 339-59.

Jagannathan, V. (1986). Corruption, delivery systems, and property rights. World Development, 127-132.

Jerez Darias, L. M., Martin-Martin, V. O., and Perez Gonzalez, R. (2012). Approximacion a una geografia de la corrupcion urbanistica en Espana. Eria, 5-18.

Kaufman, D., Kraay, A., and Mastruzzi, M. (2010). The Worldwide Governance Indicators: Methodology and Analytical Issues. World Bank Policy Research Working Paper 5430.

Lambsdorff, J. (2006). Causes and Consequences of Corruption: What Do we Know from a Cross-Section of Countries? In RoseAckerman, International Handbook on the Economics of Corruption (pp. 3-51). Edward Elgar.

Lederman, D., Loyaza, N., and Soares, R. (2005). Accountability and Corruption: Political Institutions Matter. Economic and Politics, 1-35.

Lee, M. (1994). THE COST OF THE SECOND BEST: THE PRICE OF LAND REGULATION IN ASIA . DPU Working Paper No. 62.

Long, J. S. (1997). Regression Models for Categorical and Limited Dependent Variables. Thousand Oaks, CA: Sage Publications.

Maldonado, S. (2010). Resource Windfall and Corruption: Evidence from a Natural Experiment in Peru. Working Paper.

Martín-Martín, V. O. (2010). Georeferenciando la corrupcion urbanistica en Espana. In J. O. al., La informacion geografica al servicio de los ciudadanos: de lo global a lo local (pp. 917-929). Seville: University of Seville Press. 
Mauro, P. (1997). The Effects of Corruption on Growth, Investment, and Government Expenditure: A Cross-Country Analysis. In K. Elliot, Corruption and the Global Economy (pp. 83-107). Washington, DC: Institute of International Economics.

Mitrakos, T., Akantziliotou, C., Vlachostergiou, V., and Tsolacos, S. (2014). Exploring the determinants of residential property values in a crisis: evidence from Greece. European Real Estate Society 21st Annual Conference. Bucharest, Romania: Bucharest University of Economic Studies.

Mroz, T. A. (2012). A Simple, Flexible Estimator for Count and Other Ordered Discrete Data. Journal of Applied Econometrics, 646-665.

Nyblade, B., and Reed, S. (2008). Who Cheats? Who Loots? Political Competition and Corruption in Japan, 1947-1993. American Journal of Political Science, 926-941.

Olken, B. (2007). Monitoring Corruption: Evidence from a Field Experiment in Indonesia. Journal of Political Economy, 200249.

Roodman, D. (2006). How to Do xtabond2: An Introduction to "Difference" and "System” GMM in Stata . Washington, DC: Center for Global Development.

Rose-Ackerman, S. (1975). The economics of corruption. Journal of Public Economics, 187-203.

Rose-Ackerman, S. (1988). Bribery. In J. Eatwell, M. Milgate, and P. Newman, New Palgrave Dictionary of Economics. London: MacMillan.

Serra, D. (2006). Empirical Determinants of Corruption: A Sensitivity Analysis. Public Choice, 225-256.

Sowell, T. (2009). The Housing Boom and Bust. New York: Basic Books.

Sutton, G. (2002). Explaining Changes in Housing Prices. BIS Quarterly Review, 46-55.

Svensson, J. (2005). Eight Questions About Corruption. Journal of Economic Perspectives, 19-42.

Tanzi, V. (1998). Corruption Around the World: Causes, Consequences, Scope, and Cures. IMF Staff Papers, 559-594.

Treisman, D. (2000). The Causes of Corruption: A Cross-National Study. Journal of Public Economics, 399-457.

Tsatsaronis, K., and Zhu, H. (2004). What Drives Housing Price Dynamics: Cross-Country Evidence. BIS Quarterly Review, 6578.

Windmeijer, F. (2000). A finite sample correction for the variance of linear two-step GMM estimators. London: IFS Working Papers, No. W00/19. 


\section{APPENDIX: Figures}

Figure A.1: Aggregate Corruption Counts from 2003 to 2008 - Map of Regions of Greece and Number of Zoning Corruption Counts:

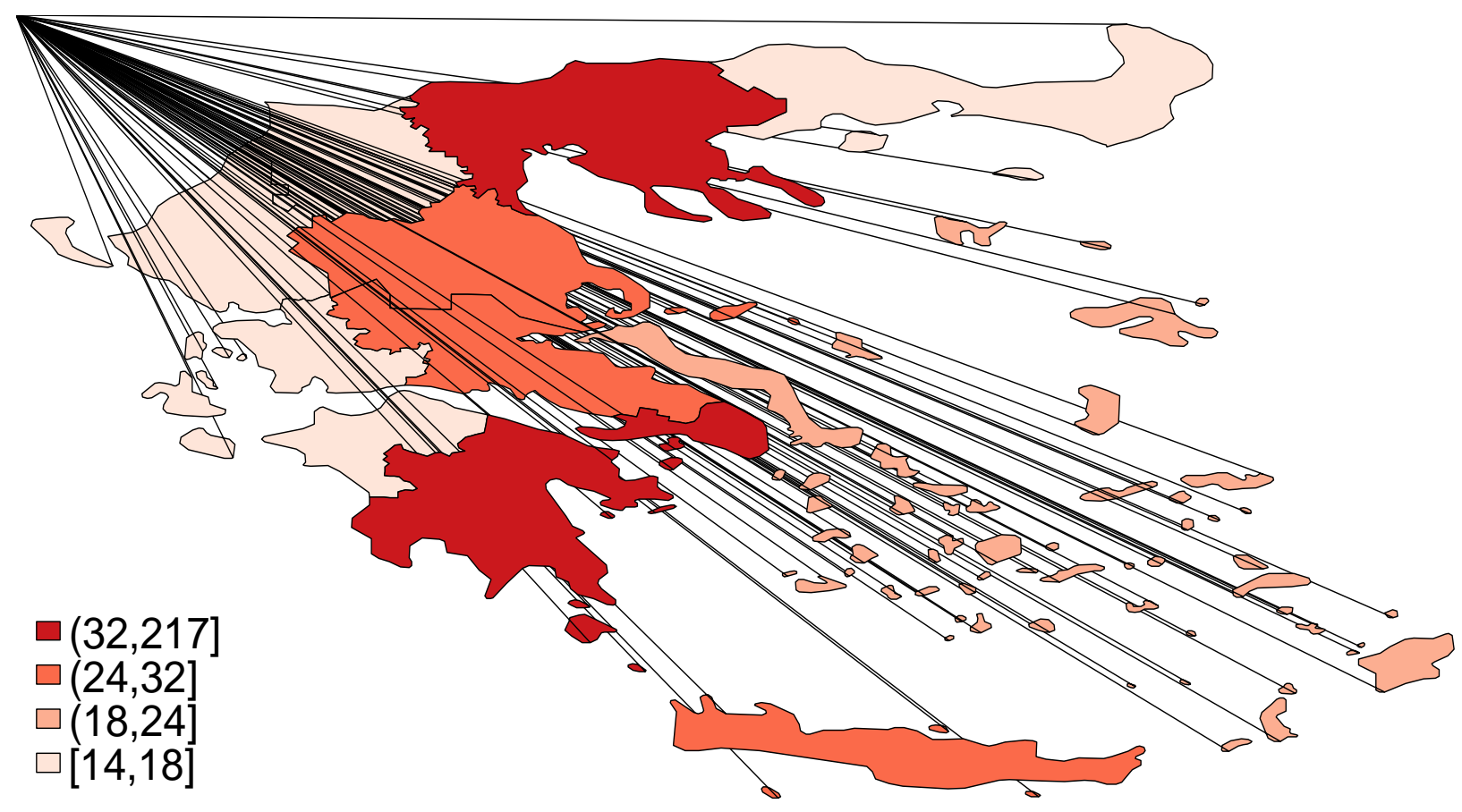

Figure A.2: Average Regional Population from 2000 through 2008 - Map of Regions of Greece and Number of Thousand Inhabitants

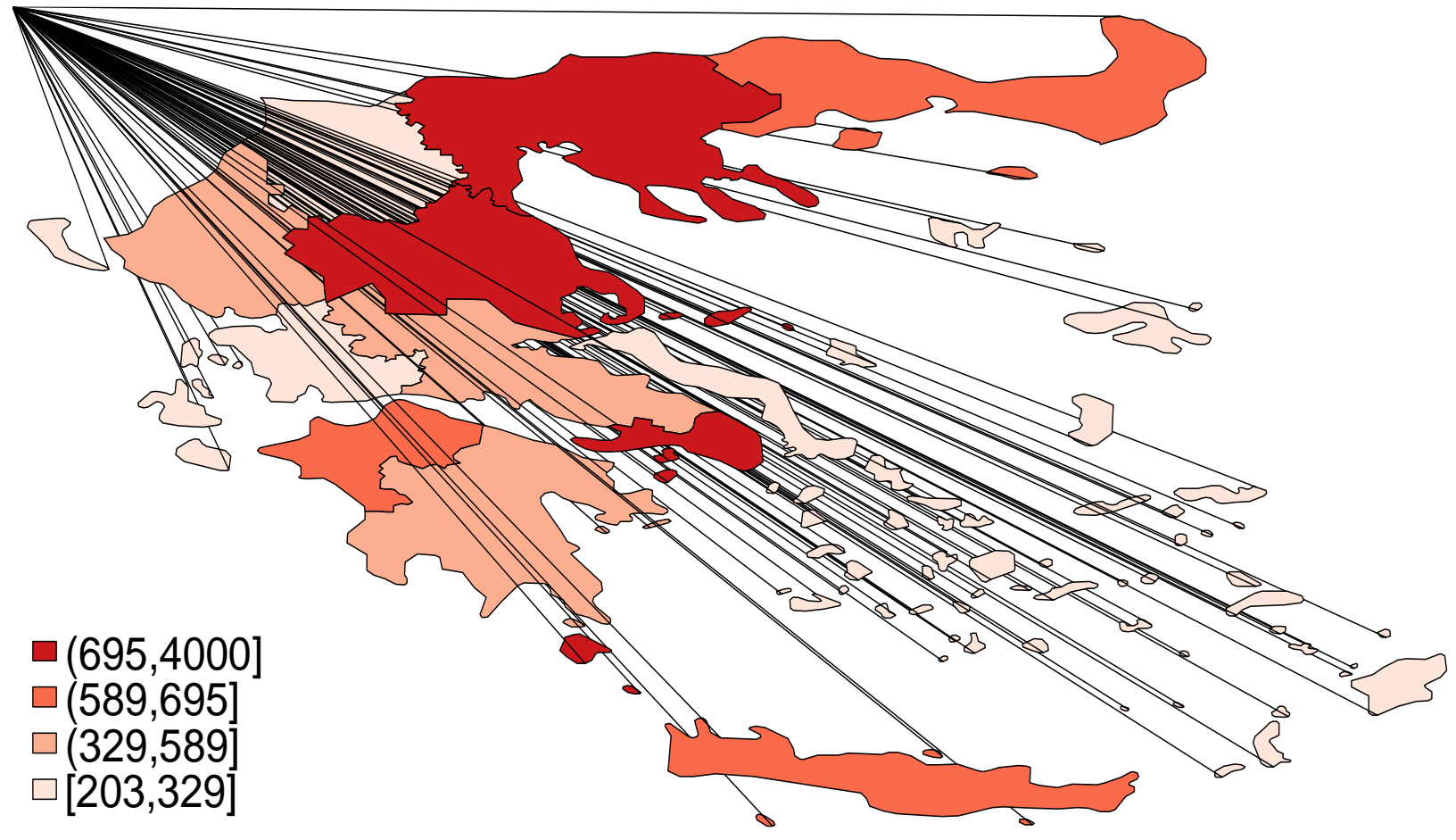


Figure A.3: Aggregate Corruption Counts from 2006 through 2008 - Map of Regions of Spain and Number of Zoning Corruption Counts:

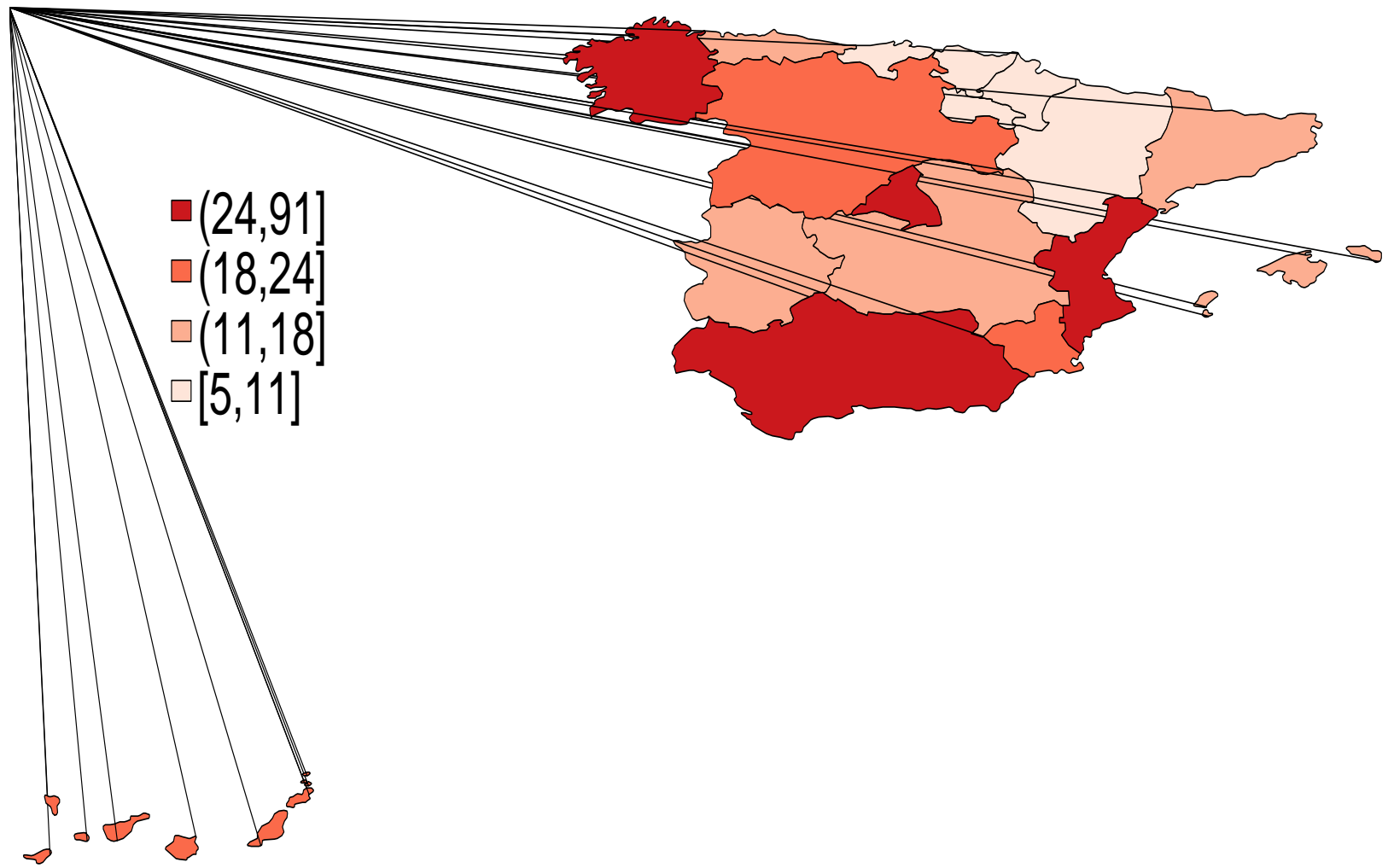

Figure A.4: Average Regional Population from 2000 through 2008 - Map of Regions of Spain and Number of Thousand Inhabitants

$\square(2.707,7.593]$

$\square(1.913,2.707]$

$\square(1.06,1.913]$

$\square[0.32,1.06]$

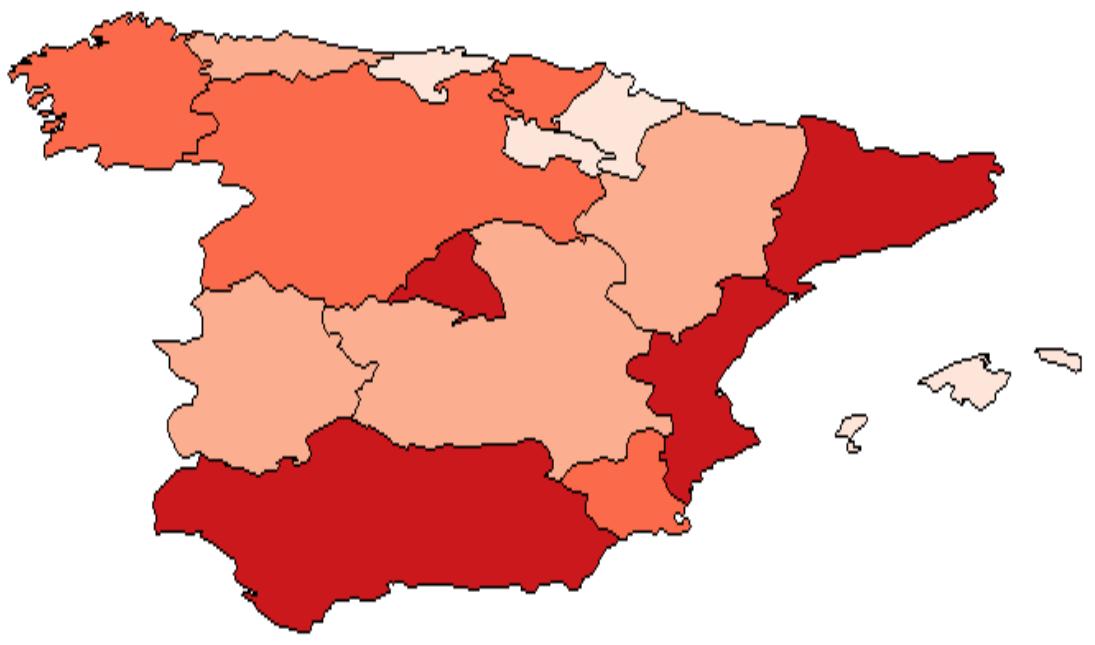

$\infty \infty_{0} \beta^{3}$ 


\section{APPENDIX: Tables}

Table A.1: Summary Statistics - Greece, N = 936

\begin{tabular}{lllll}
\hline Variables & Mean & Std Dev & Min & Max \\
\hline Corruption Counts per Month & 0.23 & 0.61 & 0 & 6 \\
Housing Prices $\left(€ / m^{2}\right)$ & $1,922.25$ & 405.29 & 1,228 & 3,071 \\
Unemployment Rate & 9.6 & 2.3 & 4.4 & 18.54 \\
Population Density & 133 & 265 & 31 & 1,058 \\
Population & 851,855 & 996,541 & 201,796 & $4,000,137$ \\
College Attainment Rate & 17.2 & 4.1 & 10.5 & 28.1 \\
New Building Permits per Month & 540 & 998 & 6 & 12,114 \\
\hline Sources: Inspectors-Controllers Body for Public Administration, Eurostat, Hellenic
\end{tabular}

Statistical Authority

Table A.2: Summary Statistics - Spain, N $=204$

\begin{tabular}{lllll}
\hline Variables & Mean & Std Dev & Min & Max \\
\hline Corruption Counts per Month & 1.86 & 2.90 & 0 & 23 \\
Housing Prices $\left(€ / m^{2}\right)$ & 1847.49 & 509.59 & 914.9 & $3,035.8$ \\
Unemployment Rate & 7.8 & 2.4 & 4.2 & 15.6 \\
Population Density & 159 & 175 & 24 & 789 \\
Population & $2,611,837$ & $2,307,037$ & 300,821 & $8,046,131$ \\
College Attainment Rate & 53.4 & 12.9 & 26.5 & 77.6 \\
New Building Permits per Quarter & 8,525 & 8,251 & 1,045 & 34,600 \\
\hline $\begin{array}{l}\text { Sources: GISAS Research Group, University of La Laguna, Eurostat, Spanish Ministry } \\
\text { of Public Works }\end{array}$
\end{tabular}


Table A.3: Data Notes

\begin{tabular}{|c|c|c|}
\hline Description & Source & Frequency \\
\hline Legal indictments of zoning officials & Inspectors-Controllers Body & Monthly \\
\hline Zoning corruption scandals & University of La Laguna, Spain & Quarterly \\
\hline Housing Prices in Greece $\left(€ / m^{2}\right)$ & Bank of Greece & Monthly \\
\hline Housing Prices in Spain $\left(€ / m^{2}\right)$ & Ministry of Public Works and Transport & Quarterly \\
\hline Seasonally adjusted unemployment rate & Eurostat & Quarterly \\
\hline Inhabitants per square kilometer & Eurostat & Annual \\
\hline Inhabitants & Eurostat & Annual \\
\hline College-degree holders aged $30-34$ years & Eurostat & Annual \\
\hline
\end{tabular}

Greek housing prices are taken from the Housing Price Index compiled by the Real Estate Market Analysis Section of the Bank of Greece. Four regional indices are available taking values from 24.18 to 102.6, overall, 2006 being the base year. There is a index for the cities of Athens and Thessaloniki that precisely maps onto the Attica and the Central Macedonia regions of analysis, respectively. The third index is computed as an average of housing prices of all prefecture (smaller administrative unit than regions) capitals - excluding Athens and Thessaloniki - and otherwise cities with populations larger than the capital of each prefecture. The fourth index is computed as the average of "other areas" which are not capitals of the prefecture they are located in. Next, we determine whether a region is rural or urban according to the 2010 OECD typology classification. Regions with a greater percentage of their population living in urban areas are assigned the third housing price ('Rest Large Cities") while more rural regions are assigned the fourth housing price index ("Smaller Urban Areas"). Out of the remaining 11 regions of Greece, excluding Attica and Central Macedonia, 2 rural regions; namely, Epirus and Thessaly, are assigned the fourth housing price index. Then, we bring information on the median price in 2013 for each prefecture from Bank of Greece's Real Estate Market Analysis Section, aggregate it to the regional level to derive the population-weighted average residential property value in each region. Lastly, we interact these latter values with the four housing price indices to introduce cross-sectional variation. 
$\underline{\text { Table A.4: Correlation Coefficients - Greece, } \mathrm{N}=936}$

\begin{tabular}{lccccccc}
\hline Corruption Counts & 1 & & & & & & \\
Housing Prices & $0.333^{* *}$ & 1 & & & & & \\
Housing Price 18-month Lag & $0.335^{* *}$ & $0.941^{* *}$ & 1 & & & & \\
Population & $0.490^{* *}$ & $0.565^{* *}$ & $0.597^{* *}$ & 1 & & \\
Population Density & $0.528^{* *}$ & $0.509^{* *}$ & $0.524^{* *}$ & $0.922^{* *}$ & 1 & \\
Unemployment Rate & $-0.118^{* *}$ & $-0.538^{* *}$ & $-0.576^{* *}$ & $-0.194^{* *}$ & $-0.183^{* *}$ & 1 \\
College Attainment Rate & $0.408^{* *}$ & $0.524^{* *}$ & $0.437^{* *}$ & $0.635^{* *}$ & $0.751^{* *}$ & $-0.243^{* *}$ & 1 \\
\hline${ }^{* * *} p<0.01 ;{ }^{* *} p<0.05 ;{ }^{*} p<0.1$. Bonferroni adjustment; & & & &
\end{tabular}

Table A.5: Correlation Coefficients - Spain, $N=204$

\begin{tabular}{lccccccc}
\hline Corruption Counts & 1 & & & & & & \\
Housing Prices & $0.261^{* *}$ & 1 & & & & & \\
Housing Price 18-month Lag & $0.244^{* *}$ & $0.971^{* *}$ & 1 & & & & \\
Population & $0.238^{* *}$ & $0.210^{* *}$ & $0.187^{* *}$ & 1 & & & \\
Population Density & $0.048^{* *}$ & $0.583^{* *}$ & $0.592^{* *}$ & $0.922^{* *}$ & 1 & & \\
Unemployment Rate & $0.081^{* *}$ & $-0.142^{* *}$ & $-0.388^{* *}$ & $0.261^{* *}$ & $-0.112^{* *}$ & 1 \\
College Attainment Rate & $0.063^{* *}$ & $0.327^{* *}$ & $0.335^{* *}$ & $0.286^{* *}$ & $0.364^{* *}$ & $-0.135^{* *}$ & 1 \\
\hline
\end{tabular}

${ }^{* * *} p<0.01 ;{ }^{* *} p<0.05 ;{ }^{*} p<0.1$. Bonferroni adjustment; 